\title{
متطلبات تطوير منهج الاحياء للمرحلة الثانوية فى ضوي تحديات القرن الحادى والعشرين
}

\section{السيد يونس اسماعيل مخمد}

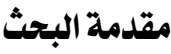

أجنبية بؤدى الى تخلف تقنى ، و الحفاظ على المصادر الطبيعيـــة مثــل الميــاه و إقامـــة مشروعات لتحلية المياه بالتقنيــة الغــشائية

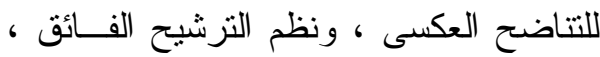
وتحلية مياه البحر بواسطة النطبيقات النووية

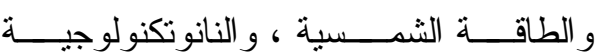

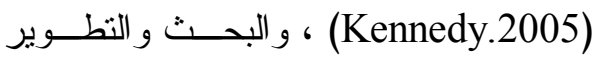
يعتبر متخلف عن العالم المتقدم ،فقـى عــام

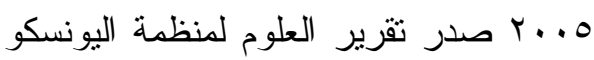
يثير بأن المنطقة العربية هى الأقل تكثئــاً

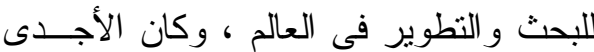
أن تركز جهودها علـى الإبتكــار العلىـى ولى الاجى

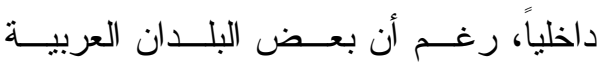
رصدت مبالغ كبيرة للبحث و النطوير مثـل

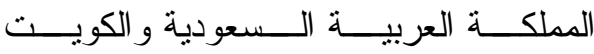
و الإمارات المتحدة ولكن مخرجات البحــث و التطوير لم تزقى إلى ما توصلت اليه الدول

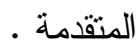

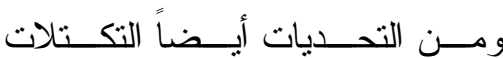
الإقتصادية الإقليمية العملاقة فهى نشكل أكثر

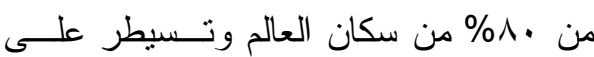

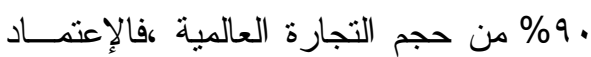

تو اجه البشرية فــى القــرن الحـــادى

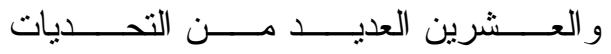
Challenges for the $21^{\text {st }}$ Century

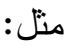

Polulation الإنفجـــار الــسكانى explosion السكانى Population Suicide فى الــدول المتقدمة ، التقدم المذهل الذى تحققه البالـــان

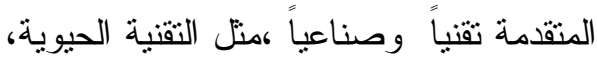
وتقنية المعلومسـات و الإتــصـالات و التقنــــة النووية للإستخدامات السلمية وتقنيات المو اد الجديدة المتقدمة منل الطاقة الثمسية وتقنيـــة النانو ، و الزر اعات المتطورة التى تتيح زيادة

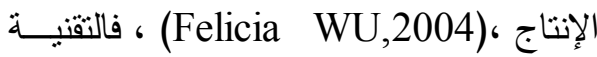
تسهم فى تتمية الإقتصاد ولها تأثير ات سلبية على البيئــة (Veronica Garcia,2012) فهى تتفس ملوثاتها الصلبة و السائلة و الغازية إلى المحيط الحيوى . لـون و المعرفة يمكن نقلها أما التقنية فينبغى أن تمارس كما يمكن تطوير ها (برنامج الأمم

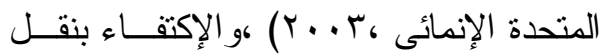
التقنية فى صورة شر اء المعدات من شركات 
(2012, 106 أن مناهج العلوم فى حاجة إلى

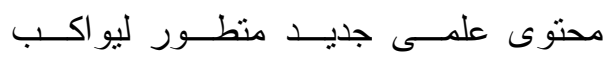

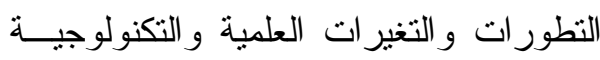

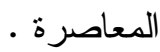

فهناك اتفاق على وجود فجوة واســعة بين ما يتعلمه الطلاب فى المدرسة وتلك التى يحتاجونها فى الحياة و العهـلـل فـى مجتمـــع عصر العلم و المعرفة ،و أن المناهج الحالية لم تعد كافية لإعداد الطلاب للحياة و العدــل

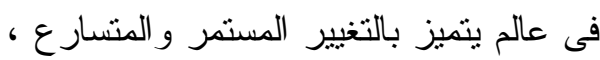

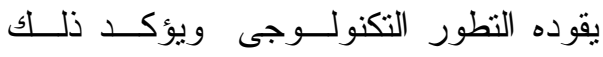
(Bybee ,2010,213) فى كتابــه تــدريس العلوم من منظور مهار ات القــرن الحــادى

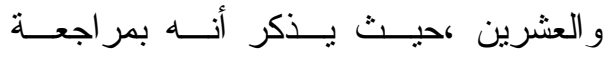

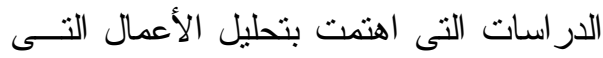
يتطلبها سوق العدــل فـــى القـــرن الحـــادى و العشرين لتحديد المتطلبات التــى تتطلبهـــا

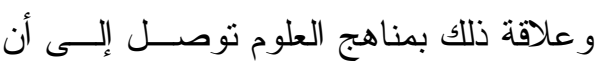
نو اتج التعلم فى بر امج العلوم الحالية لم تعـــ كافية لإعداد الطلاب للحياة و العمل فى القرن

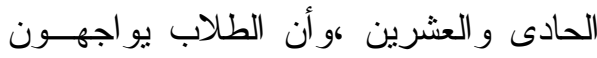
خطورة أنهم يعدون لأعمال اختقت أومرشحة للاختفاء فى هذا القرن •

ونتيجة لذلك نادت الآر اء بأنه يجــب

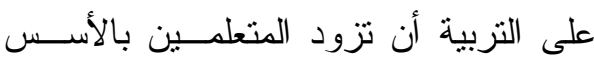

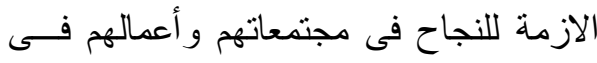
القرن الحادى والعشرين ،وفى هذا الــسياق
الجماعى على الذات له آثاره الإيجابية مسن ناحية اتخاذ القر ارات فى المجالات المختلفـــة فعـرف هــذا العــصر بعـصر التكــتلات الإقتصادية .

تحدى البطالة فــى ظـــل الأوضــــاع الإقتصادية المتزدية ، فالتغير يحدث بسرعة ويؤثز بقوة على نوعية محددة من العمالـــة

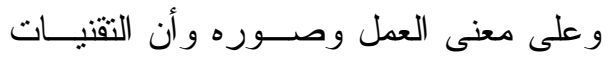
الحديثة وراء التغير الحــادث فــى العهـلـل

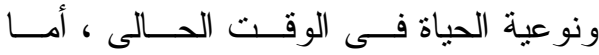
المستقبل فيصعب التتبؤ بما سيحدث فيه من تغير ات وما يجد فيى الطلب على المهــارات ونوعياتها مما يستوجب إعادة هيكلة العملية

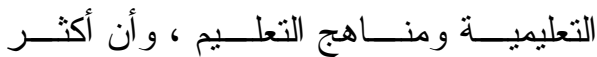

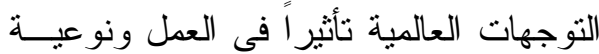

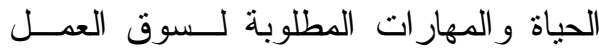
تتمنتل فى الأنظمـــة الرقميـــة ، و العولمـــة ، وتغير موقع العمـلـ ، وزيــادة الــسئولية الثخصية ،لذا لابد من من التعاون والتكامل لبناء إقتصاد قوى يتحدى العولمة.

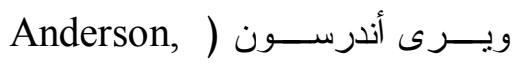
(2012, 105 أن التقدم العلمى و التكنولوجى (a) يفرض على العمليــة التعليميــة ضـــرورة مسايرة هذا الو اقع بالتفاعل بايجابية معه ويتم ذللك من خلال تطوير المناهج الدراسية . ويؤكد كل من أندرســون وســيث

Anderson , ) ، (Smith.2010,211) 
تؤكد نتائج بعض البحـــوث الثربويـــة

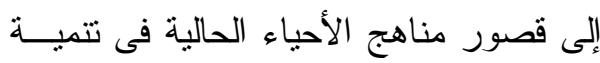

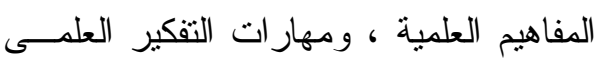

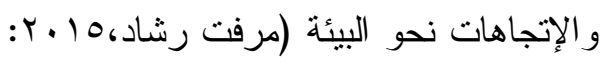
هץ) ؛ وقصور مناهج الأحياء فى تـضـمين

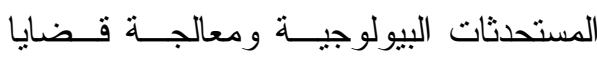
الأخلاقيات البيولوجية (محمد بــن صــالح، .$(\vee \wedge:$ : . . 9

وكما يؤكد التقريــر النهـــئي للجنــة

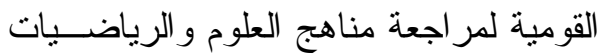

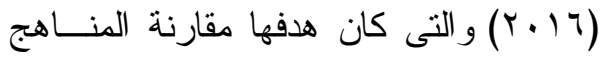

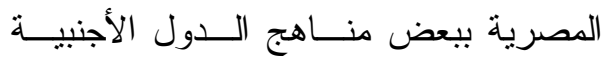
المتقدمة من بينها الولايات المتحدة الأمريكية

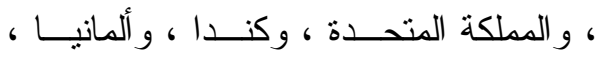
وفنلندا ، وسنغافورة ؛ إلى أن مناهج الأحياء الحالية لاترفى للمستوى العالمى وليست محل ونل

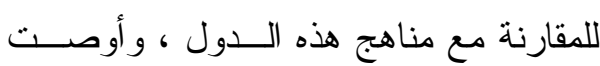

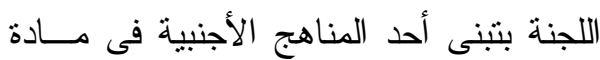
الأحياء (وز ارة التربية و التعليم ،7 (1 بـ).

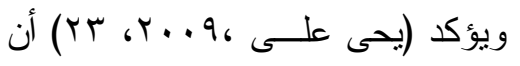

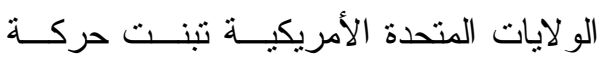

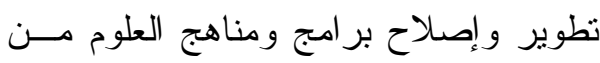
خلال العديد من المشاريع التزبوية الفاعلـــة منذ الثمانينات ، ومنها مـشروع عـ " المجــال و التتاسق " Scope and (Coordination ) (Sequence) (C\&SS)

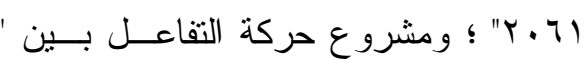

سعى العديد من المؤسسات المعنية بــالتعليم

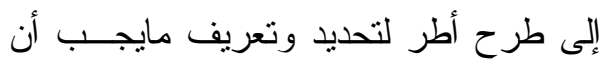

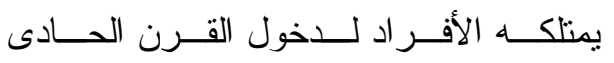

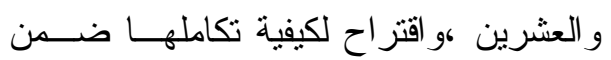

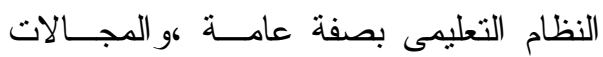
الار اسية الأساسية بصفة خاصة. وفى عـام 2005 وضــعت منظمــة

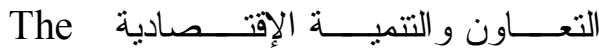
Organization for Economic Cooperation and Development( إطار ها لمتطلبــات القـرن OECD,2005) الحادى و العشرين مسن خــلال مبــادرنين ،الأولى برنامج تحديد وتعريف المتطلبــات كو الثانية البرنامج الــدولى لتقيــيم الطــلاب PISA حيث شكلت المبادرة الأولى الإطــار النظرى للتانية ،وفى هذا الإطار تــم تقـسيم منطلبات القرن الحادى و العشرين إلى ثلاث

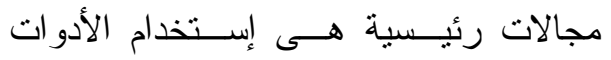

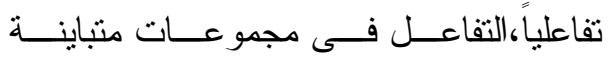
كو التصرف بشكل مستقل.

\section{الإطار النظرى للبحث}

و هناك ضرورة ملحسـة تــدعو إلـى تطوير مناهج العلوم بصفة عامة ، ومنـــاهج

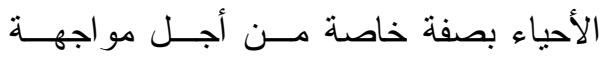

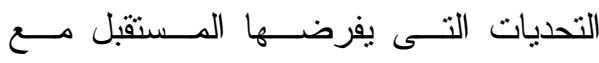

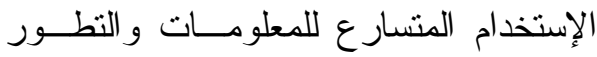
التكنولوجى وتز ايد المـشكلات الإقتــصادية و الإجتماعية و البيئية. 
الرياضيات و الهندسة و التكنولوجيا ـ وتسمح

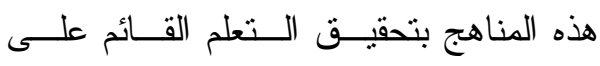

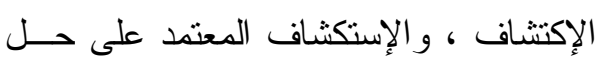

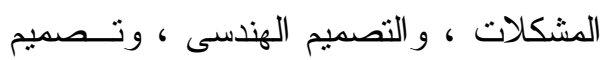

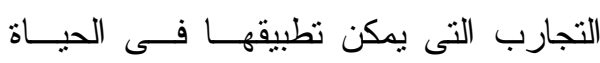
(Burrows,) Breiner, Keiner, الو اقعية .$\&$ Behm,2014,70)

و هنالك إتجاهــات ثلاتكـة مـستقبلية

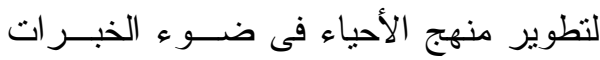

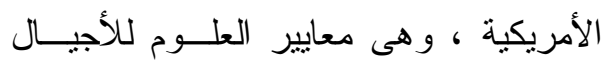

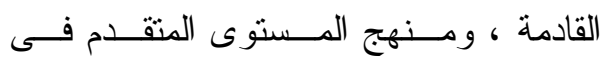
البيولوجى ، ومدخل البيولوجيا الحديثة للقرن الو احد و العشرين.

الإتجاه الأول : معاييز العلوم للأجيال

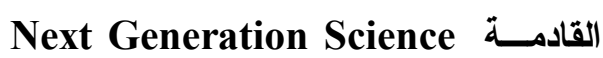
Standards (NGSS:

توجهت الولايات المتحدة الأمريكيــة نحو إصلاح مناهج العلوم فى ضوء المعايير القومية للتربية العلمية فى عـام (1919 (19) ،

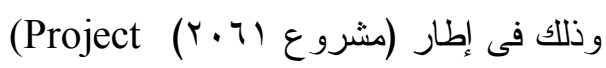
.2061)

الإتجاه الثـانى : مــنهج المسـتوى

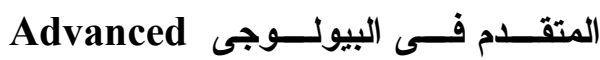
Placement Biology

مناهج المستوى المتقدم فى الأحيــاء تزكز على المفاهيم الكبرى ، و الممارسـات العلمية المعرفية و المهار ات من أجل إنجــاز

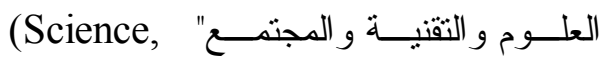
Technology and Society) (STS) ومشروع حركة " المعايير القوميــة لتعلــيم

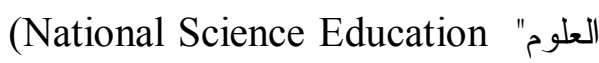
Standards (NSES)

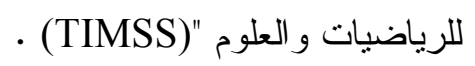

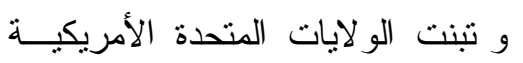

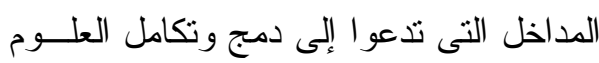

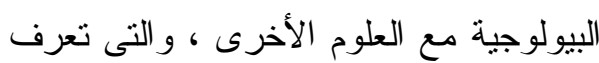

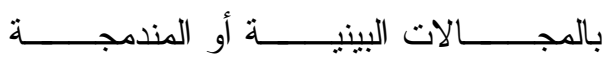
(Interdisciplinary)

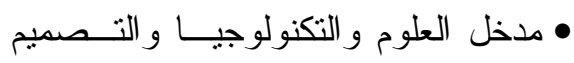
الهندسى و الرياضيات (STEM)

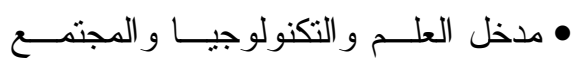
و البيئة (STSE)

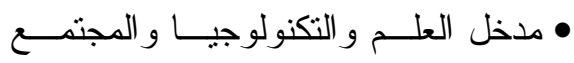
(National Academy oof Science ,2014) • مدخل البيولوجى و التكنولوجيا و الهندسة و الرياضيات (BTEM) ويمكن لمنهج الأحياء أن تحقق طفرة

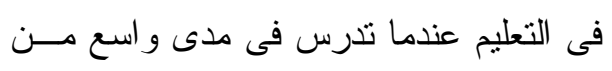
التكامل و الإندماج مع العلوم الأخرى ومنهــــا

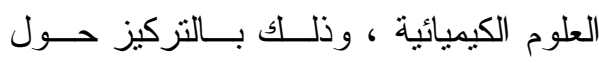
در اسة موضوعات وقضايا علمية إجتماعيــة

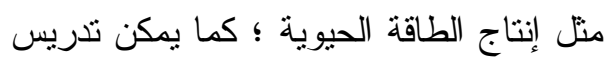

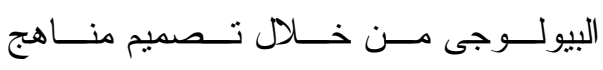

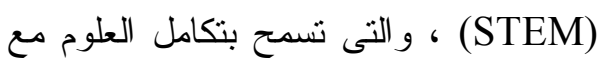


و العالمى عن طريق رفع الــوعى بالتتميــة

المستدامة (Mijung \& Diong, 2012).

مجهودات مؤسسة (BSCS) فــى تطــوير

دراسة علم الأحياء.

The Biological Sciences Curriculum Study (BSCS)

BSCS البرامج التى تقدمها B

Environmental

$$
\text { 1- المـدخل البيئكى }
$$

ruman Approach المدخل الإنسانى

Molecular

r- المــــــل الجزيئـــى

Approach

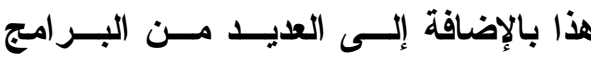

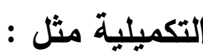

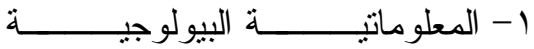

Bioinformatics و مشروع الجينــوم

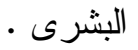

r- إستخدام التكنولوجيا لدراسة البيولوجيــا

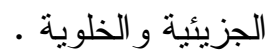

r- المخ : فهم البيولوجيا العصبية من خلال در اسة الإدمان.

مشروع البيولوجى والبيوتكنولوجى بجامعة

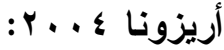

The Biology Project The University of Arizona,2004

تصدر المشروع أن قـضضايا الــصحة

العالمية و الجودة فى التعليم ، و الإختبــار ات الوراثية تعتبر من القضايا البيولوجية المعقدة
مهام محددة ، وبنـــاء الأدلـــة ، و التتبـــؤ ، و التحقق من التفـسيرات القابلـــة لإختبــار

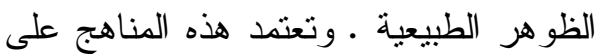

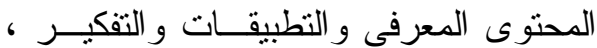
وتقوم مناهج المسنوى المتقدم فــى الأحبـــاء

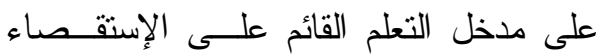
(Inquiry -based Learning) . (Schultz,2012)

الإتجاه الثالث: مـــخل البيولوجيـا

New الحديثة للقرن العـادى والعسشرين Biology Approach for 21 st

:Century

ومدخل البيولوجيــا الحديثـــة للقــرن

الو احد و العشرين ظهر نتيجة لمجهودات عدة

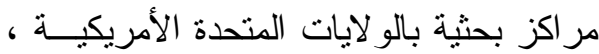

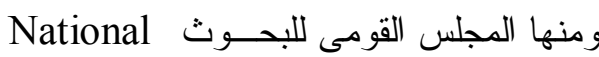
Research Council للعلــــوم ( Academry of Science)، ومعهـ الـصحة Institute of (medicine) (National Research of Engineering)(National Academy .Council,2009)

و الدراسات الحديثة تؤكد إتجاه مناهج

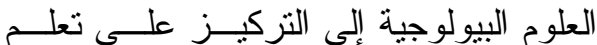

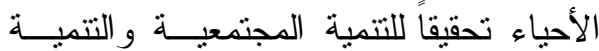

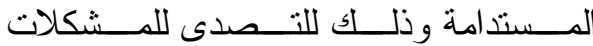
الإجتماعية و البيئية على المسستوى المحلـى 
الطلاب أن يتعلمو ا مهارات النتور العلىى

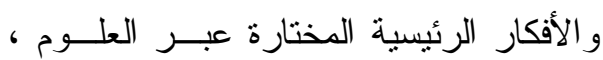

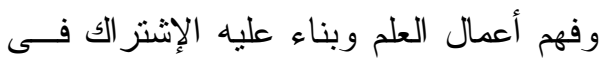
الحوار الناقد المرتبط بالمعضلات الـسياسية

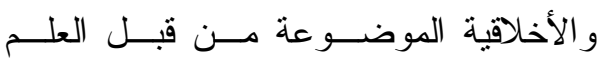

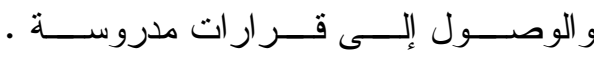
(Collins,D.,et al ., 2001)

التجربة العربية

كما ثم الإتفاق على الإســتفادة مــن بعض المناهج الريادية المتطورة ، و التى أخذ الإنى بها فى مناطق مختلفة من العالم منل : 1- مشروع B.S.C.S (المــدخل البيئسى Ecological Approach

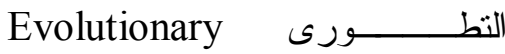

· (Approach

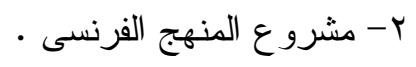

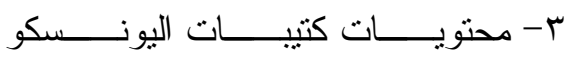

\section{.UNESCO}

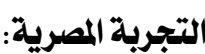

ولو نظرنا إلى مناهج الأحيــاء فــى

مصر نجد أنها أصبحت مناهج تاريخية فـى نـى الصى

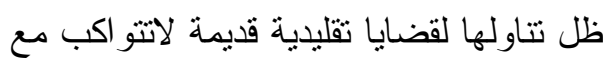
المشكلات المعاصرة و لاالتقام العلمى المذهل

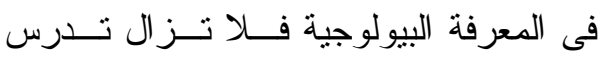
موضوعات مرتبطة بالمورفولوجى ، وتقسيم

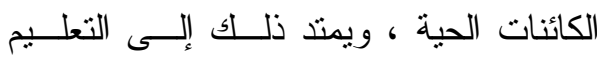

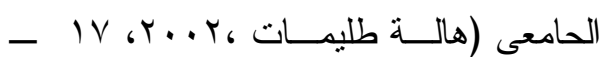

التىى تو اجه المجتمــع اليــوم ، و المـــو اطنين يحتاجون لفهم المبادئ البيولوجية الأساســية لئون "Basic Biological Principles " يتخذوا القرارات السليمة، ويهدف مسشروع البيولوجى إلى تحسين الفهم فى كـلـل أنحــــاء العالم عن طريق الإمـــداد بقاعــدة مجانيـــة

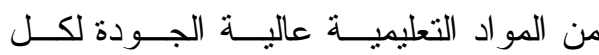
المستو يات.

التجربة الإنـجليزية

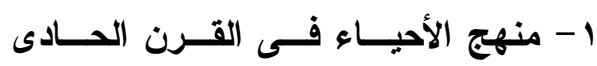
و العشرين (المنهج الجديد)

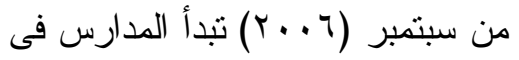
إنجلتر ا وويلز فى تدريس منهج علوم جديـــ

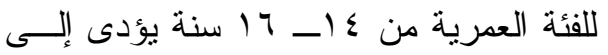
The General الحـصول علـى شـــهادة Certificate of School Education(GCSE) إستطلاعية لمنهج العلــوم للقــرن الحــادى وفي و العشرين وذللك على (V^) مدرسة ثــانوى منذ سبتمبر r . . r، و وعلى ما يقرب من أكثر

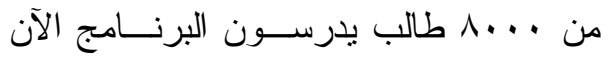

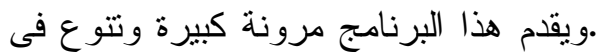

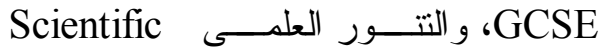
Literacy و الأفكار الأساسية عن العلم.

وقد إستتنجت لجنة الفحص أنه فـى

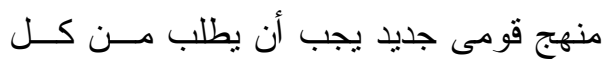


إستر اتيجية قائمة على بعض أساليب الــتعلم

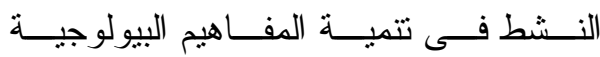

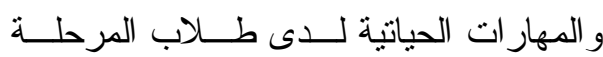

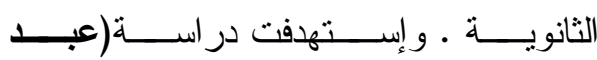

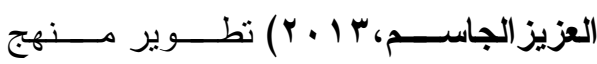

البيولوجى فى المرحلة الثانوية بدولة الكويت

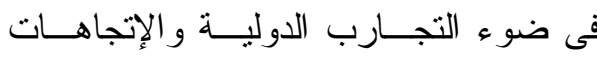
المعاصرة لتتمية بعض المهـــار ات الحياتيـــة

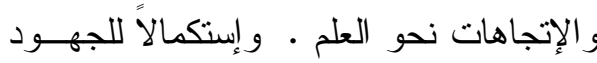

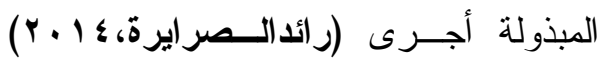
در اسة هدفت إلى نطوير منهج الأحياء فـى إنى

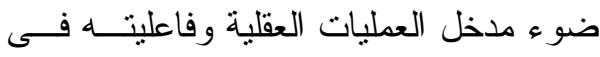
تتمية المهارات الحياتية لاى طلاب الــصف

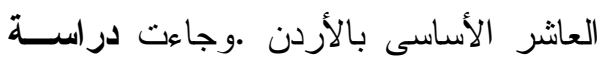

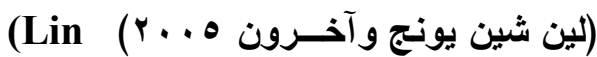
ع, Chen - Yung,et.,2005) مجموعة قو امها (185) معلم أحياء تتوعـــ

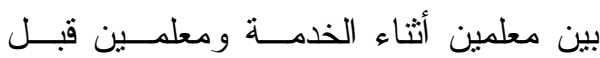
الخدمة. وقد أجريت الدر اسة علــى معلىـى لئى الأحياء،در اسة ( Sungus, Tekkaya \& Geban, (2006 هدفت هذه الدر اسة إلــى (إسى تقصى أثز إستخدام التعلم القائم على المشكلة

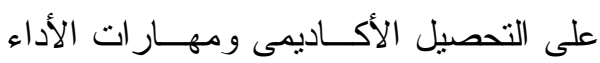
لحل المشكلات فى وحدة الجهاز الإخر اجسى a

(Yalcin,Karahan,Karadenizli,\&S :alin,2006)
1 1) ضـــارباً التقـــدم المعرفــى و البحــوث

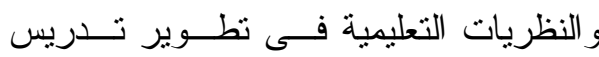

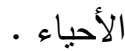

ولم يزيد التطوير عن كونه مجـرد

حذف أو إضافة أو إستبدال لموضو عات دون لنون أسباب علمية أو نربوية واضحة ، وإن أدى إنى

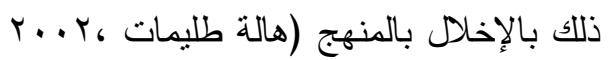
. الاراسـات و البحوث التى إهتمــث بتطــوير منهج الأحياء للمرحلة الثانوية

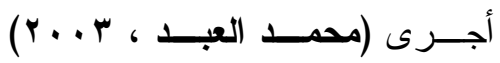

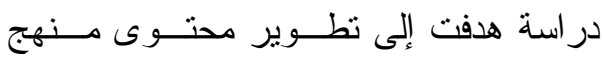

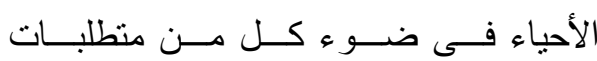

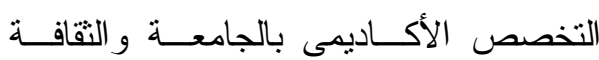

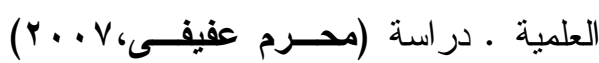
هدفت هذه الدراسة إلى تصميم منهج مقترح

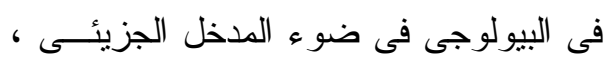

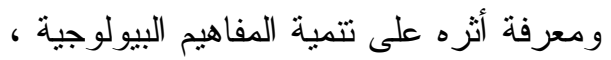

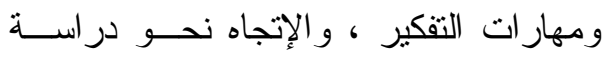

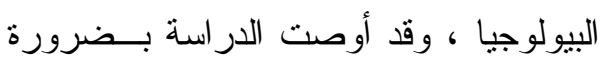

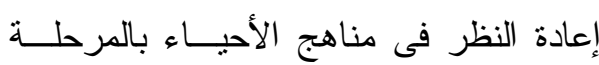
الثانوية فى مصر ل

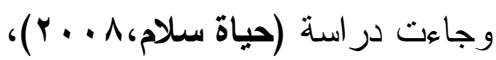
تناولت هذه الدراسة تطوير مــنهج العلــوم

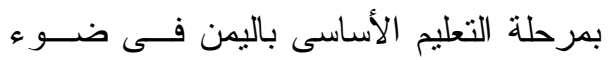

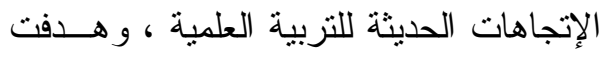
در اسة (مديحة حمدى، ب ا ـ ب)، إلى فاعليــة 
للاحصاء أن تطبيق و اســتخدام تكنولوجيــا المعلومات والاتصالات وهى إحدى متطلبات القرن الحادى و العشرين فى التعليم فى الدول العربية غالباً ما يأتى منأخراً (معهد اليونسكو فئر

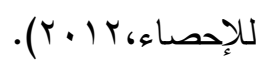

ومن خلال منهج الأحياء المطور فىى

ضوء متطلبات القرن الحــادى و العـشرين يمكن تتمية التفكير الناقد و المنظومى لطلاب

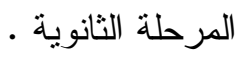

بالإضافة إلى نتائج الاراسة الإســنطلاعية التى قام بها الباحث وهى كالتالى:

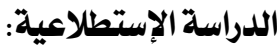

* - إستهدفت الدراسة الإستطلاعية التعرف

على مدى تلبية محتويات كتب الأحبــاء الحالية (طبعة 19/1 19/ץ) بالمرحلة الثانوية لمنطلبات تطوير منهج الأحيــاء

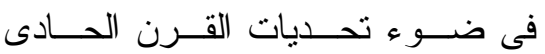

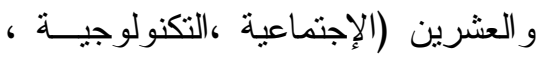

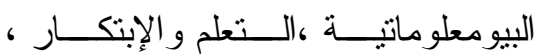
الإقتصادية ،البحثية الإستقصائية ،تحدى

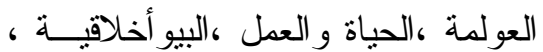
الصحية الوقائية ،الإيكولوجيــة ) مسـن وجهة نظر المعلمين .

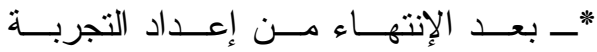
الإسنطلاعية تم عرضها على مجموعة الإنهاء من المحكمين وذلك للتعرف على آرائهر فيما يتعلق بمدى مناسبتها لقيــاس مــــا
هدفت هذه الدر اسة إلى تقــصى أثـــر

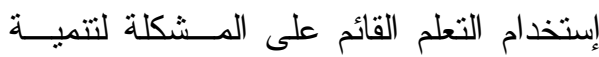
مهار ات كل من التفكير العلمى ومهارات حل المشكلات ، وحل النتاقضات . وبعد إطلاع الباحــث علـى بعـض

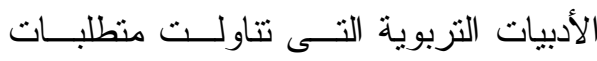
تطوير المناهج التعليمية بصفة عامة ومناهج

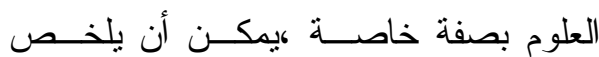
الباحث أهم هذه المتطلبات كما يلى: 1 - متطلبات بيو معلو مانية

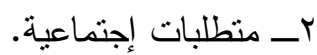
rــ منطلبات بحثية إستقصائية. عــ منطلبات تكنولوجية. ○ـ منطلبات التعلم و الإبتكار . 1- - منطلبات إيكولوجية.

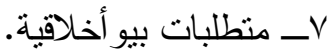
^ــ متطلبات الحياة و العمل. 9- متطلبات صحية وقائية. • (1 متطلبات تحدى العولمة .

$$
\text { إلـ منطلبات إقتصادية. }
$$

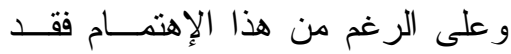

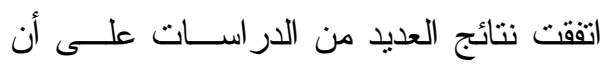
تضمين منطلبات القرن الحادى والعـشرين فى المناهج ضعيف وليس علــى المـسنوى Blank et.al \&Hiong (2013) المطلوب ولى ويؤكد تقرير معهد اليونـسكو and Osman 
كتب الأحياء بالمرحلة الثانوية للمتطلبات البيو اخلاقية .

r- بالنسبة للمتطلبــات البيومعلوماتيــة: بلغت النسبة المئوية لدرجة اهتمام كتب الأحياء بتلبية المتطلبات البيومعلوماتيـــة من وجهة نظر معلمى الأحياء (6.3\% بــصورة مرتفعـة ، 9.5\% بــصورة منوسطة ، 84.5\% بصورة منخفضة ) وتؤكد هذه النتائج انخفاض درجة تلبيـــة كتب الأحياء بالمرحلة الثانوية للمنطلبات البيو معلومانية . rــ بالنسبة للمتطلبات الإيكولوجية: بلغــــ

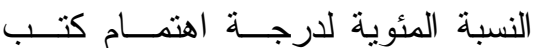
الأحياء بتلبية المتطلبات الإيكولوجية من وجهة نظر معلمـى الأحيـاء (3.8\%

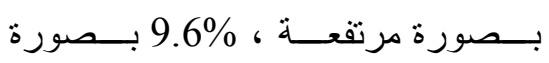

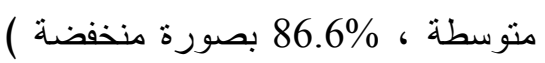

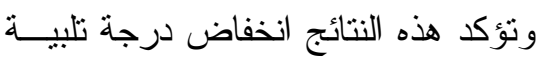
كتب الأحياء بالمرحلة الثانوية للمنطلبات

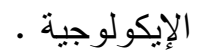

عـ بالنسبة للمتطلبات التكنولوجية : بلغت النسبة المئوية لدرجــة اهتـــام كتــب الأحياء بتلبية المتطلبات التكنولوجية من لن النيه وجهة نظر معلمـى الأحبـاء (2.5\% بصورة مرتفعسة ، 14.5\% بـصورة منوسطة ، 83\% بصورة منخف ضضة ) وتؤكد هذه النتائج انخفاض درجة تلبيـــة
صمدت من أجله ، وقد أجريــت بعـــ العديلات التالية : - التان

• كتابة المؤشرات بصورة بسيطة سهلة وقابلة للإستيعاب من قبل المعلم • • كتابة الهدف من إستطلاع الر أى .

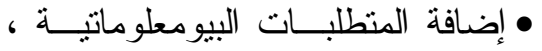
و الصحية الوقائيــة ، و الإيكولوجيــة

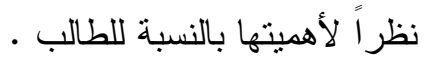
• الإكتفاء بأربعة مؤشرات لقطط عن كل

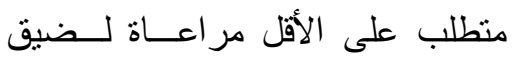
وقت المعلم بحيث تكون شاملة قــدر

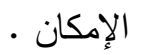

*- تم تطبيق إسنطلاع الر أى فى صــورته

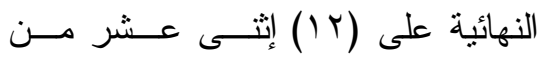

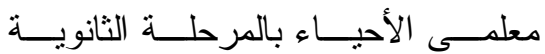

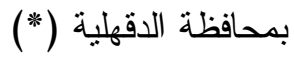

وأكلت النتائج انخفاض تلبية كتـبب الأحياء بالمرحلة الثانوية لمتطلبات القــرن الحادى والعشرين من وجهة نظر المعلمين كمايلى :

1ـ بالنسبة للمنطلبات البيو أخلاقية :بلغـــت النسبة المئوية لدرجــة اهتمـام كتــب الأحباء بتلبية المنطلبات البيو اخلاقية من وجهة نظر معلمـى الأحيـاء (8.3\% بصورة مرتفعسة ، 13.8\% بـصورة منوسطة ، 78.85\% بصورة منخفضة)

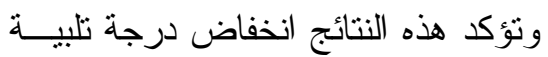


وتؤكد هذه النتائج انخفاض درجة تلبيــة كتب الأحياء بالمرحلة الثانوية للمتطلبات الصحية الوقائية .

^ــ بالنسبة لمنطلبات تحـــى العولمــة :

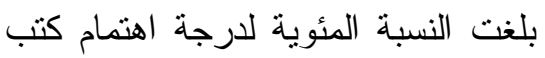
الأحياء بتلبية المتطلبات الصحية الوقائية من وجهة نظر معلمى الأحياء (7.35\% بصورة مرتفعسـة ، 13.8\% بـصورة متوسطة ، 78.85\% بصورة منخفضة) وتؤكد هذه النتائج انخفاض درجة تلبيــة كتب الأحياء بالمرحلة الثانوية لمنطلبات

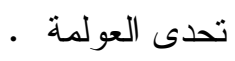

9- بالنسبة للمتطلبات الإجتماعية : بلغــــ

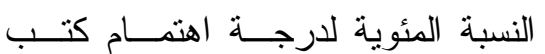
الأحياء بتلبية المتطلبات الصحية الوقائية من وجهة نظر معلمى الأحياء (11.5\%

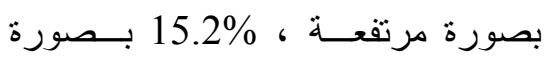

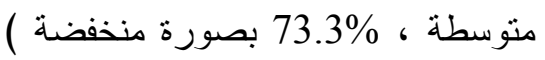
وتؤكد هذه النتائج انخفاض درجة كونة تلبيــة كتب الأحياء بالمرحلة الثانوية للمنطلبات

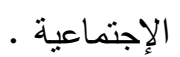

• إـ بالنسبة لمتطلبات التعلم والإبتكــار: بلغت النسبة المئوية لدرجة اهتمام كتب الأحياء بتلبية المنطلبات الصحية الوقائية من وجهة نظر معلمى الأحياء (6.94\%

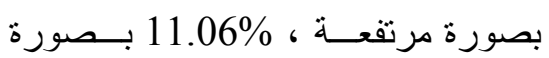

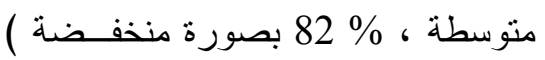

كتب الأحياء بالمرحلة الثانوية للمنطلبات

$$
\text { التكنولوجية . }
$$

○ـ بالنسبة لمتطلبات الحياة و العمل : بلغت

النسبة المئوية لارجــة اهتمــام كتـبـ

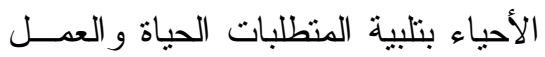
5ن وجهة نظر معلمى الأحياء (5.9\% بــصورة مرتفعسة ، 9.7\% بــصورة منوسطة ، 84.4\% بصورة منخفضة ) وتؤكد هذه النتائج انخفاض درجة تلبيـــة كتب الأحياء بالمرحلة الثنانوية للمتطلبات الحياة و العمل . لاحل باء

7- بالنسبة للمتطلبات البحثية الإستقصائية

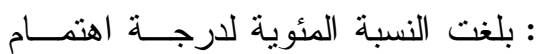
كتب الأحياء بتلبية المنطلبــات البحثيـــة

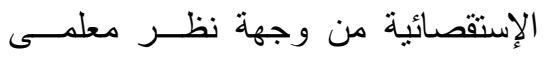

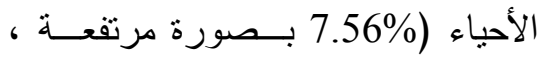
13.04\% بصورة متوسطة ، 79.4\% بصورة منخفضة ) وتؤكد هذه النتـائج

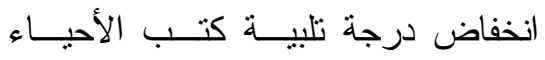

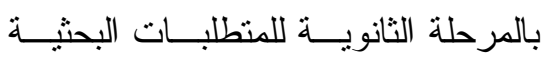
الإستقصائية . بالئة

V- بالنسبة للمتطلبات الصحية الوقائيــة : بلغت النسبة المئوية لدرجة اهتمام كتب الأحياء بتلبية المتطلبات الصحية الوقائية من وجهة نظر معلمى الأحياء (8.7\% بصورة مرتفعـة ، 12.45\% بــصورة منوسطة ، 78.85\% بصورة منخفضة) 
إعداداً علمياً متميز اً لمو اجهة تحديات القــرن

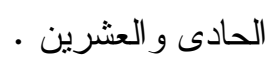

مما سبق يتضح أنتــا بحاجــة إلـى

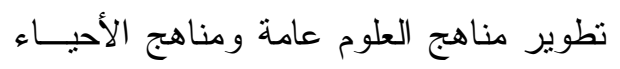

بصفة خاصة لكى تكون قادرة علــى تلبيــة متطلبات القرن الحادى و العشرين.

وللتصدى لهذه المـشكلة يحـاول البحــث

$$
\text { الإجابة عن السؤال الرئيس التالى : }
$$

كيف يمكن تطوير منهج الأحياء فـى لـى

المرحلة الثانوية فى ضوء منطلبات القــرن

الحادى و العشرين وتحدياته ؟

• أسئلة البحث ولعثريث

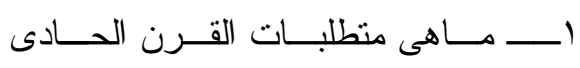

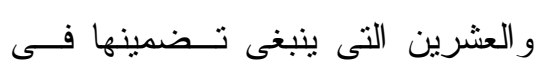

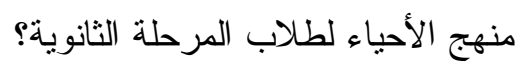

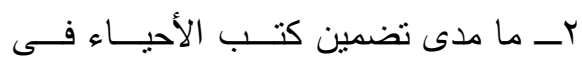

المرحلة الثانوية لهذه المتطلبات ؟ بات

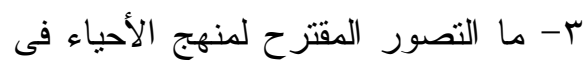

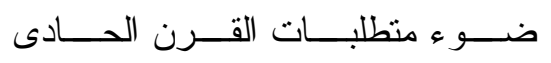

$$
\text { و العشرين؟ }
$$

ع - ما فاعلية المنهج المطور فــى ضـــوء

متطلبات القرن الحادى و العشرين فـى لـى

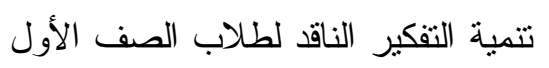

$$
\text { الثانوى؟ }
$$

0- ما فاعلية المنهج المطور فــى ضـــوء

منطلبات القرن الحادى و العشرين فـى لـى
وتؤكد هذه النتائج انخفاض درجة تلبيـــة كتب الأحياء بالمرحلة الثانوية لمتطلبات

$$
\text { - التعلم و الإبتكار }
$$

11- بالنسبة للمتطلبات الإقتصادية: بلغت

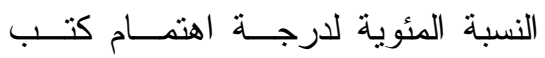

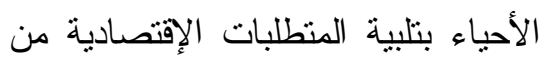

وجهة نظر معلمى الأحيــاء (10.36\%

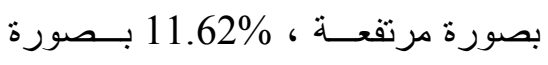

منوسطة ، 78.02\% بصورة منخفضة)

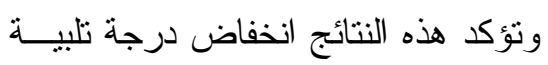

كتب الأحياء بالمرحلة الثانوية للمنطلبات

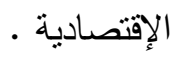

مشكلة البحث الإن

تتفق الدراسات على أن مناهج الأحياء

علــى المـستويين العـالمى Blank et.al (2001) \& Hiog and Osman (2013)

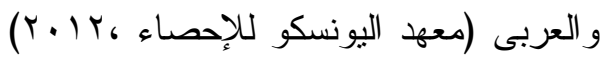

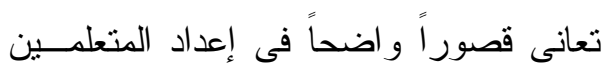
للحياة و العمل فى القرن الحادى و العــشرين

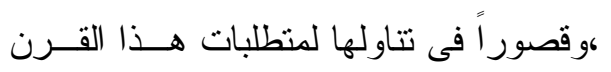

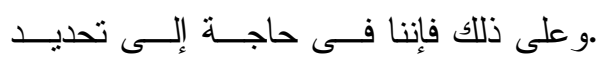
متطلبات القرن الحادى و العشرين التى يمكن

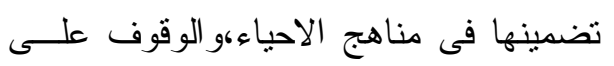

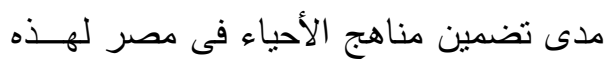

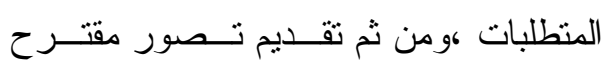
لتضمينها فى مناهج الأحياء بحيث تقوم هذه

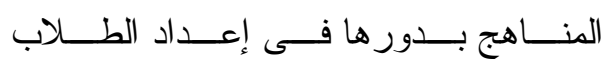


• معرفة فعالية تدريس المنهج المطــور

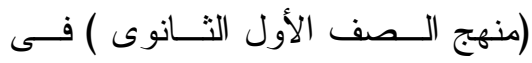

ضو ءمنطلبات القرن الحادى و العشرين

على تتمية إمتلاك طلاب الصف الأول

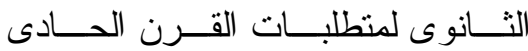

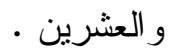

وضع تصور مقترح لما يجب أن تكون

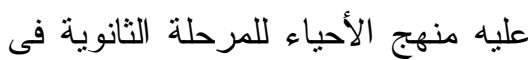

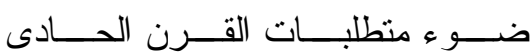

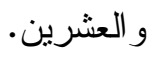

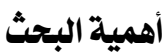

'ــ إلقاء الضوء على الوضع الر اهن لمنهج

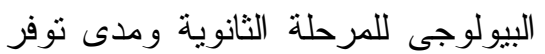

منطلبات القرن الحادى و العشرين بها.

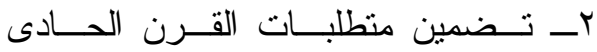

و العشرين في منهج الأحيــاء لطـــلاب

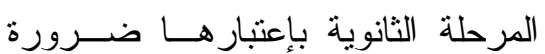

ملحة و إتجاهاً عالمياً يخدم كافة منــاحى لئل

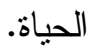

\section{ومن الناحية النظرية :}

يوفر البحث الحالى نموذجــا لــدمج

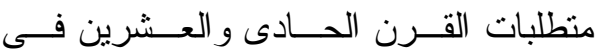

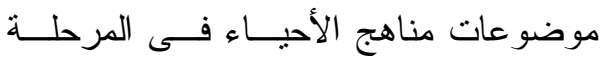

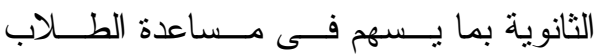

الدارسين لهذا المنهج على التفاعل المثر مع هع

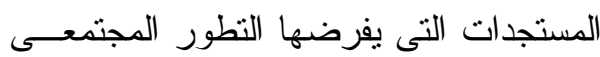

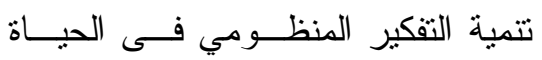

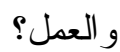

Tــ ما فاعلية المنهج المطور فــى ضـــوء

منطلبات القرن الحادى و العشرين فـى

تتمية الوعى بمتطلبات القرن الحــادى

و العشرين لاى طلاب المرحلة الثانوية؟

Vـــا العلاقة الإرتباطيــة بـين إمــتلاكك

طلاب الصف الأول الثانوى لمنطلبــات

القرن الحادى و العـشرين ومسـستويات

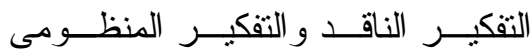

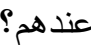

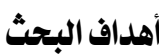

يهدف البحث الحالى إلى :

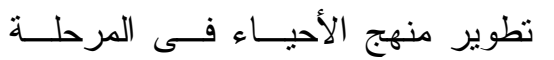

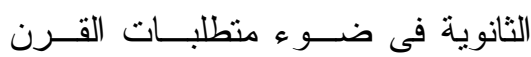

الحادى و العشرين .

معرفة فعالية تدريس المنهج المطـــور

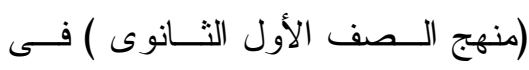

ضو عمنطلبات القرن الحادى و العشرين

على تتمية التفكير الناقد لــدى طـــلاب

الصف الأول الثانوى .

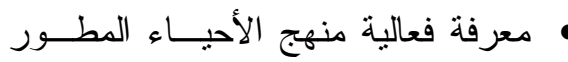

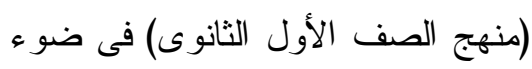

منطلبات القرن الحادى و العشرين على العى

تتمية التفكير المنظومى لــدى طـــلاب

الصف الأول الثانوى 
التقويم) منــــاهج الأحبــاء بالـــصفوف

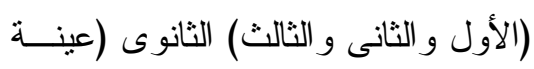

الدر اسة التحليلية الوصفية)

rــ قياس الفاعلية للمنهج المطــور علــى

تجريب وحدتين دراسية مسن المــنهج

المطور على مجموعــة مــن طــلاب

الصف الأول الثانوى فى تتمية التفكيـر

الناقد و التفكير المنظومى لاى طــلاب

$$
\text { المجمو عة التجريبية. }
$$

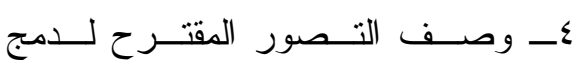

المتطلبات من خلال محتــوى منـــاهج

الأحياء فى المرحلة الثانوية

○ـ مجموعة العينة التجريبية من طــلاب

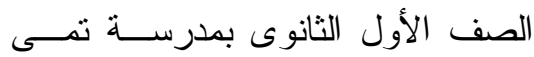

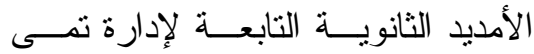

الأمديد التعليمية . الامديد التوبية

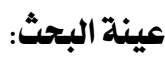

تنقسم عينة البحث إلى:

اــ عينة تحليلية وصفية وتتمنل فى منـــاهج

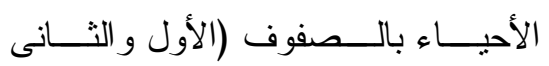

و الثالث) الثانوى بمحتوياتها المتمنلة فى بالث

(الأهـــــاف و المحتويــــات و الأنـــشطة

$$
\text { و أساليب التقويم). }
$$

r- عينة الدر اسة التجريبية (طلاب الــصف

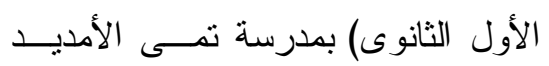

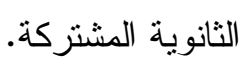

\section{ومن الناحية التطبيقية :}

ينعكس دمــج هـــه المنطلبــات فـى

موضو عات مناهج الأحياء على إعـــداد

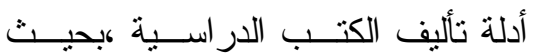

يضمن تــو افر هـــه المنطلبــات فـى لـ

$$
\text { محتو اها . }
$$

يمكن استخدام هذ النموذج فــى بنــاء

نماذج اخرى فـى مجــالات در اســية

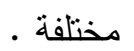

التأكيد على مدى اهية هذه المتطلبات

لكل من مخططى المناهج و المـسؤولين

عن التربية العلمية.

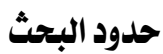

إقتصر البحث الحالى على الحدود الآتية:

اــ متطلبات القرن الحــادى و العـشرين

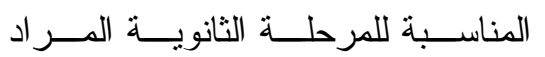

تضمينها بمنهج الأحياء ( البيو أخلاقية،

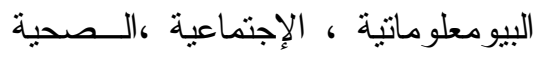

الوقائية ،التعلم و الإبتكار ، التكنولوجية،

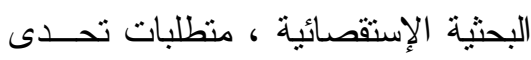

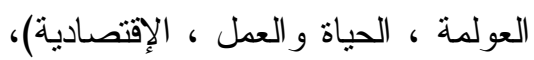

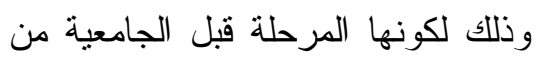

التعليم العام التى ينبغى من خلالها بناء

$$
\text { هذه الأسس لدى الطلاب . }
$$

r-ـ عينة تحليل المحتــوى المتمثلـــة فـى

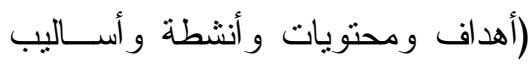


الطلاب منطلبات القرن الحادى و العـشرين

يجب أن ندرس لهم بشكل مختلف عما كنــا

نفعله من قبل ،و أن المحاضـــر ات التقليديــة

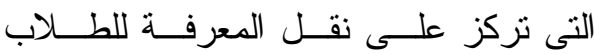
لايمكنها تحقيق ذلك.

وفى نفس السياق هدفت دراسة عبــــ

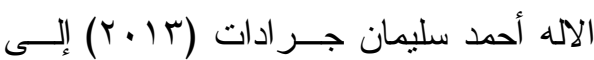
استقصاء أثز برنامج إثر ائى فى مادة الأحياء

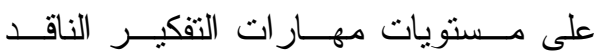
و اكتساب المفاهيم العلمية و الإتجاهات العلمية

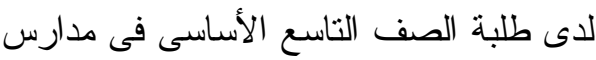

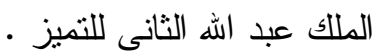
كما هدفت در اســـة مؤيســـ حسـسين محسـسن

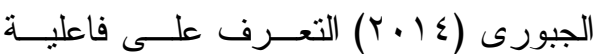
برنامج (Risk) فى التحصيل لــدى طــلاب الصف الخامس العلمى فـى مـــادة الأحيــاء

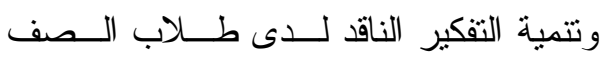
الخامس فى مادة الأحياء .

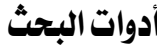

قام الباحث بإعداد الأدوات التالية: اـــأداة تحليل الأهداف العامــة لمنـــاهج الأحياء بالمرحلة الثانوية لتلبية منطلبات تطوير ها فى ضـــو ء تحـديات القــرن

$$
\text { الحادى و العشرين. }
$$

rـــ أداة تحليل محتــوى منـــاهج الأحيــاء

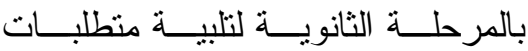

تعددت الدراسات التي عنيت بالاهتمام بمتطلبات القرن الحادي و العشرين: جاء الدليل القوى فى در اسة مؤسـسـة

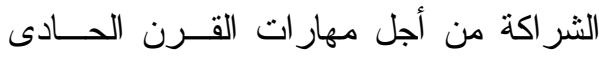
و العشرين P21 (9 . . r) و التى انطلقت من افتز اض مؤداه أن النجاح فى الدر اسة و الحياة

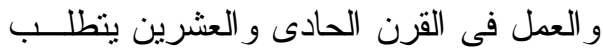
امتلالك الطلاب لمتطلبــات القــرن الحـــادى

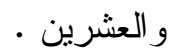

وقد أجمع الخبر اء على ما ينبغــى أن تكون عليه مجالات أهداف تعليم وتعلم العلوم المناسبة للقرن الحادى و العثرين حيث هدفت Osman Marimuthua(2013) در استـــة إلى الوصول إلى منطلبات التقكير الأساسـية فىى القرن 21 التى ينبغى دمجها فى منــــاهج العلوم الثانوية الماليزية ، و لأهميتها هــدفت

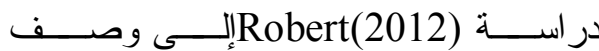
المنطلبات الضرورية فــى القــرن الحــادى و العشرين وعلاقتها بتحدياتــهـ ، وتوصــلت الار اسة إلى أنه إذا أردنا مواجهة تحــديات القرن الحادى و العشرين بفاعلية فإن الجيــل القادم يجب أن يمتلك متطلبات التفكير الناقد، التفكير الكلى ،الإستدلال العملـى ،الإبتــــار و التخيل .

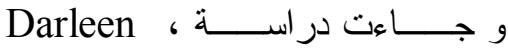
Rosefsky;(2012) حيث اعتمـدت هــذه الدر اسة على افتر اض مؤداه أنه كى بـــتعلم 
الحـــادى و العــشرين ،المنمنلـــة فــى

المتطلبات (البيو أخلاقية، البيومعلوماتية ، البناتين الإجتماعية ،الصحية الوقائيــة ،الــتـعلم

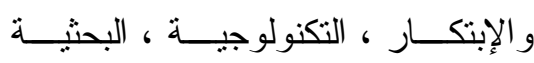

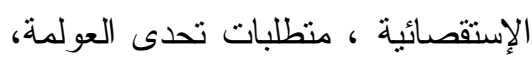

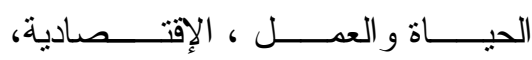
الإليكولوجية).

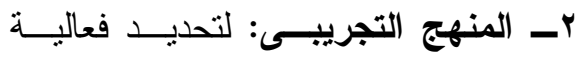
تدريس محتـوى وحهـنى (الأســاس

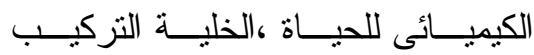
و الوظيفة) المطورتين لتلبية متطلبــات تطوير مناهج الأحياء فى ضوء تحدئ تحديات القرن الحادى و العشرين لتتمية التفكيــر الناقد و التفكير المنظومى لدى طــــلاب الصف الأول الثانوى. التصميم البحثي:

تعتمد الدراسة على التصميم القبلــي

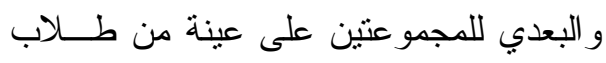
الصف الأول الثانوي:

1- المجموعة التجريبية: و هي عينــة مــن طلاب الـــف الأول الثـانوي التــي ولهي تدرس وحدنين مسن مــنهج الأحيـاء المطور • بل

r- المجموعة الضابطة: وهي مجموعة من

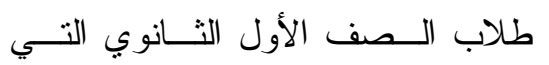
تدرس نفس المحتوى المدرسى الموجود

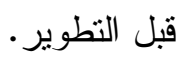

تطوير ها في ضـــو ء تحــديات القـرن الحادى و العشرين. بــــأداة تحليل أنــشطة منـــاهج الأحيــاء

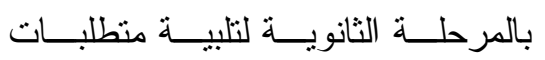
تطوير ها في ضـــو ء تحــديات القــرن الحادى و العشرين.

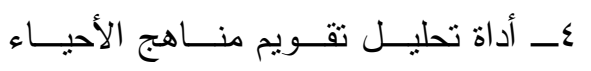

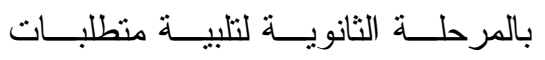
تطوير ها في ضـــوء تحــديات القــرن

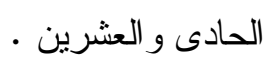
ه- إختبار للتفكير الناقد فى بعض متطلبات

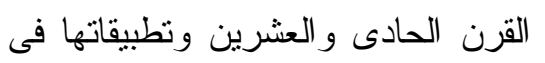
منهج الأحياء.

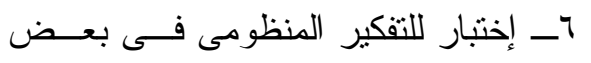

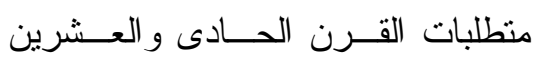
وتطبيقاتها فى منهج الأحياء .

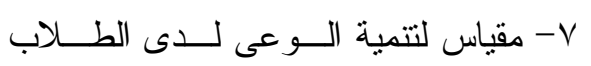
بمنطلبات القرن الحــادى و العـشرين وتطبيقاتها فى الحياة و العمل . إستخدم الباحث المنهجين التاليين: اــ المنهج الوصفى التحليلى: فى تحليـلـ

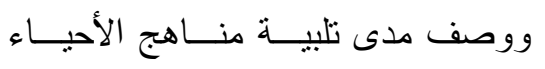
(الأهداف ، المحتوى، الأنسشة، مأساليب

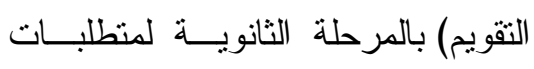

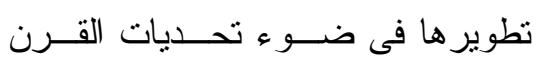




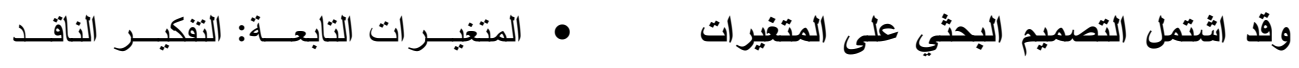
التالية:

• المتغير المستقل: منهج الأحياء المطور الثكل التالي يوضح التصميم البحثي

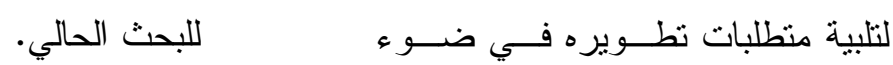
تحديات القرن الحادي و العشرين.

التطبيق البعدي

التطبيق القبلي

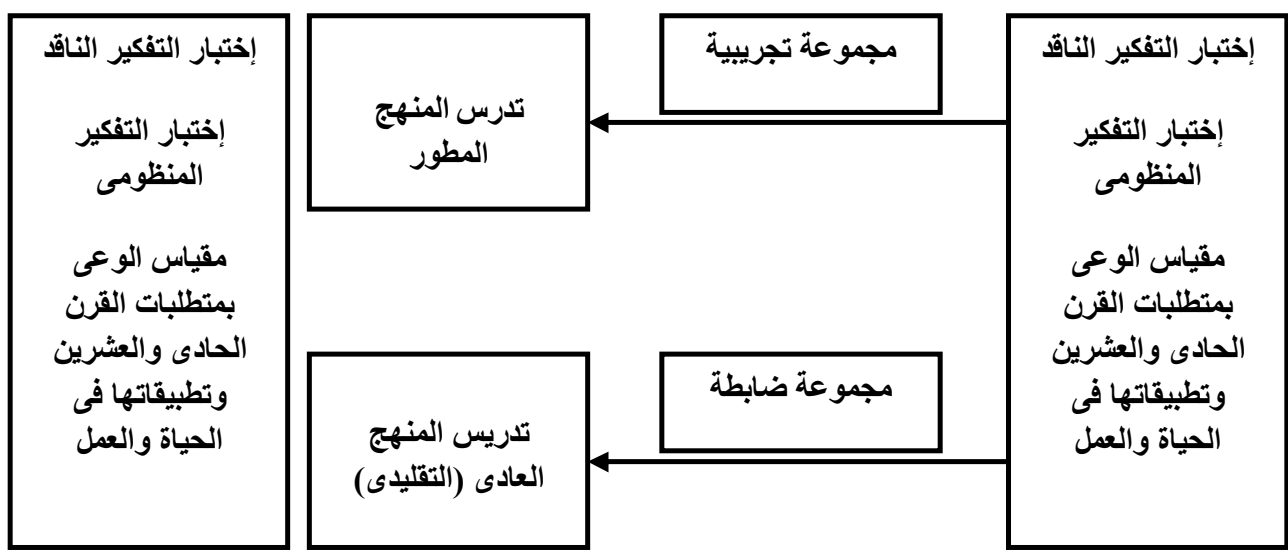

التصميم التجريبى للبحث الحالى

\section{فروض البحث}

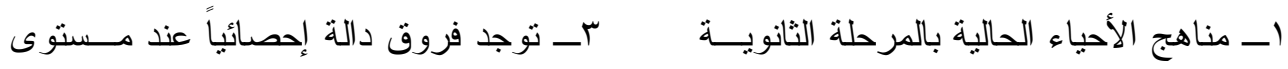

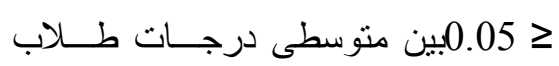

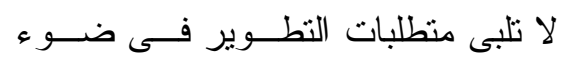

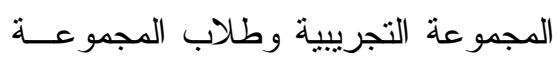
تحديات القرن الحادى و العشرين.

الضابطة فى النطبيق البعـدى لإختبـــار

r- توجد فروف دالة إحصائياً عند مـسنتوى

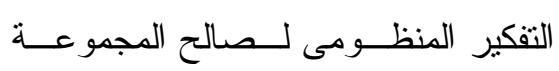

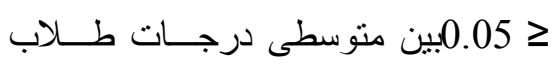

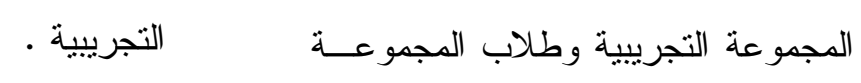

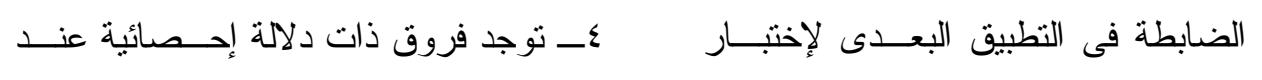

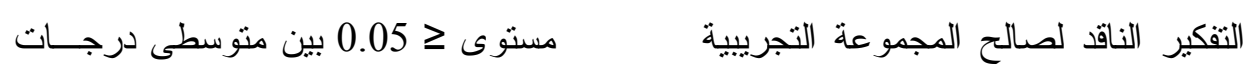

طلاب المجموعة التجريبية فى التطبيقين 


\section{ـ مصطلحات البحث}

متطلبات:كلمة منطلبات جمع لكلمة "

متطلب" ويقصد به أمر أو عل براد تحقيقه

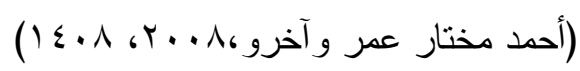

متطلبات القرن الحادى والعـشرين :

كما عرفتها الثراكة من أجل منطلبات القرن

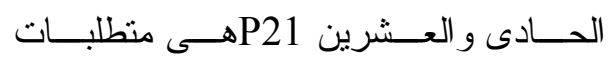

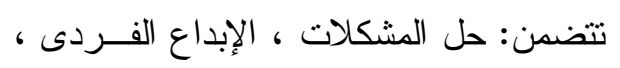

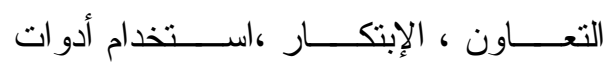

التكنولوجيا ،القابلية للتكيف و القدرة على حل الابل

$$
\text { المشكلات (P21,2006). }
$$

وإجرائياً يمكن القول بأنها مجموعـــة

من القدرات الضرورية لـضمان اســتـعداد

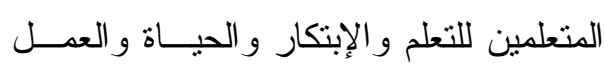

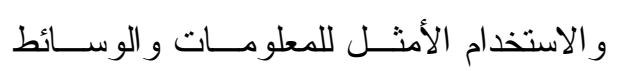

و التكنولوجيا فى القرن الحادى و العشرين .

تعريف المنهج :إن المنهج الحـديث

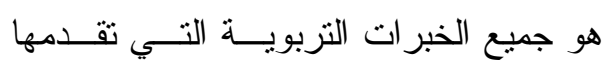

المدرسة إلى التلاميذ داخل الفصل أو خارجه الخير

وفق اهداف محددة وتحت قيادة سليمة لتساعد على تحقق النمو الثنامل من جميع النـــواحي الجسمية و العقلية و الاجتماعية و النفسية.

\section{Curriculum}

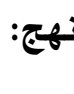

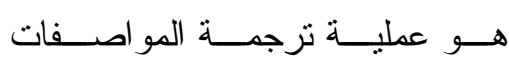

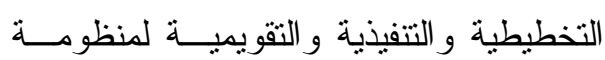

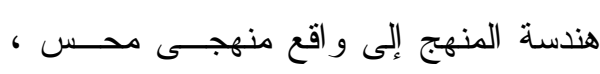

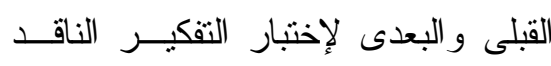

وذللك لصالح التطبيق البعدى .

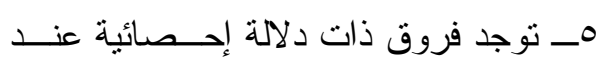

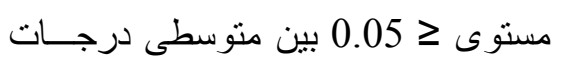

طلاب المجموعة التجريبية فى التطبيقين

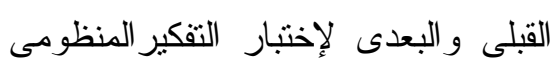

وذلك لصالح التطبيق البعدى .

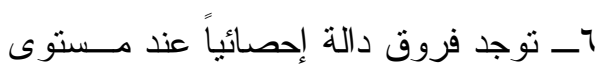

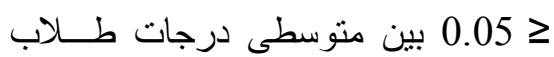

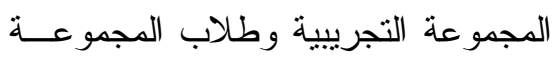

الضابطة فى النطبيق البعـدى لمقيـاس

الوعى بمتطلبات القرن الحادى و العشرين

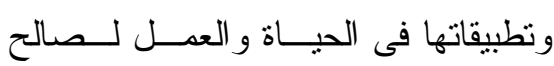

طلاب المجموعة التجريبية .

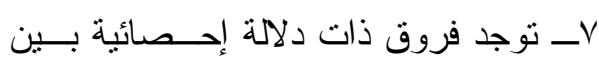

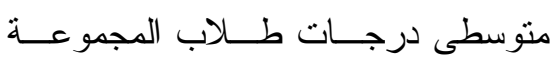

التجريبية فى التطبيقين القبلى والبعـدى درهيط

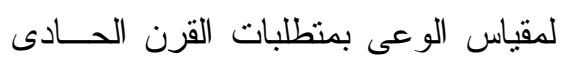

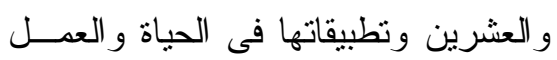

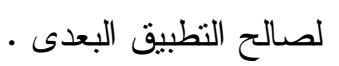

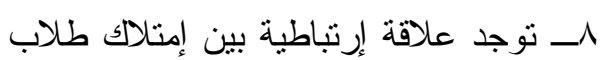

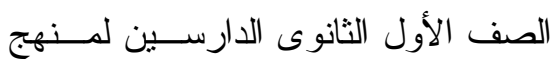

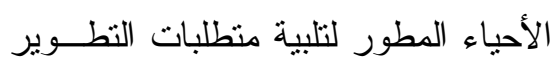

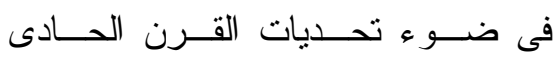

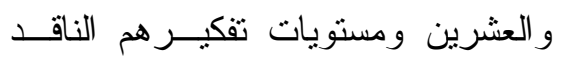

و التقكير المنظومى. و ومنئ. 
ويعرف

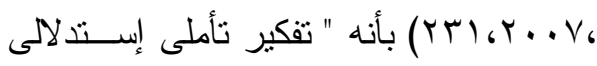

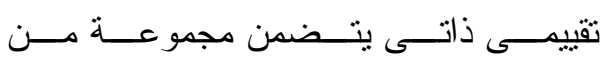

الإستر اتيجيات و العمليات المعرفية المتداخلة

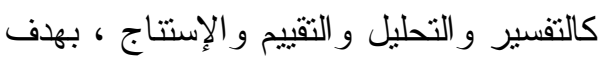
تفحص الآر اء و المعتقدات و الأدلة و البر اهين

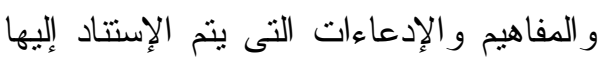

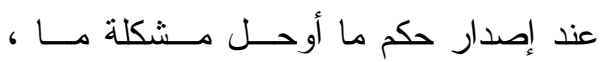

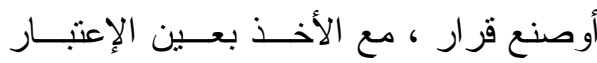

$$
\text { وجهات نظر الآخرين ". }
$$

التفكير المنظومي:" منظومسـة مــن

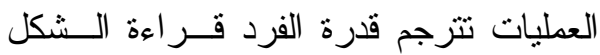
المنظومى و إدر الك علاقاته و غستخلاص هذه العلاقات وتكملتها ومن ثم رسم الثكل بجميع

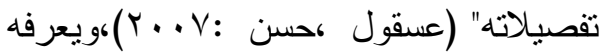

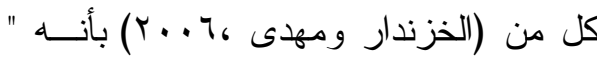
منظومة من العمليات العقلية التى تكامل بين عمليات التفكير من تحليل للموقق ، ثم إعادة تركيب مكوناته بمرونة بطرق متعددة التتظيم فى ضو ء الهدف المنشود". ويعرف كل من عفانة ونشوان التفكير

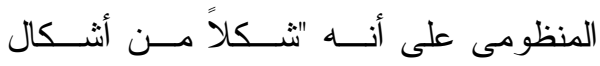
المستويات العليا فى التفكير ،فيكون الفرد من التهن خلاله قادراً على الرؤية المستقبلية الــشاملة

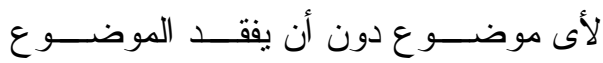
جزئياته ،أى إنتقال الفرد من التفكير بصورة دون بون
بـشكل يــضمن تحقيــق أهــــاف المــنهج و إستمر اره وبقائه كنظام فى التربية المدرسية

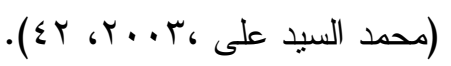

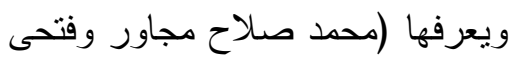

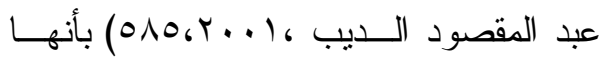
عملية إجر اء تعديلات مناسبة فى بعـض أو أو أه

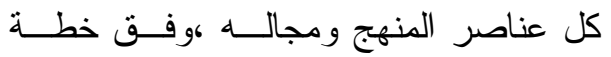
مدروسة من أجل تحسين العمليــة التربويــة ورفع مستو اها.

\section{ويعرفها الباحث إجرائياً:بأنها عمليــة}

إخخال التعديلات المناسبة على مناهج الأحياء

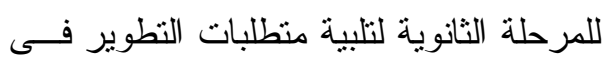
ضوء تحديات القــرن الحــادى و العــشرين

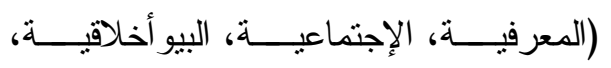
الإيكولوجيـــة، الحيـــاة و العمـــل ، الـــتـعلم

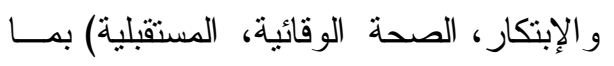

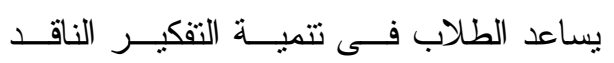
و التفكير المنظومى لديهر التفكير الناقد: القدرة علــى تحريـر

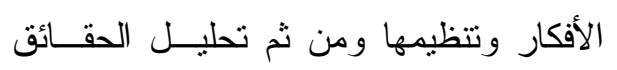

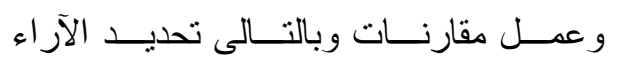

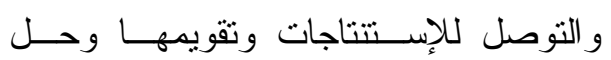

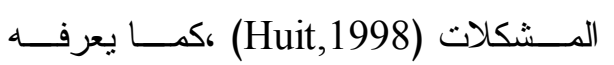

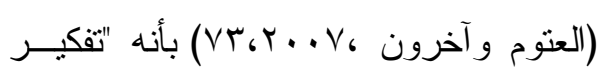

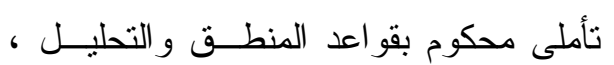
يمارس فيه الفــرد الإقتر اضـــات و التفــسير وتقويم المناقتات و الإسنتباط ". 


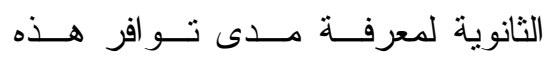
المتطلبات بها.

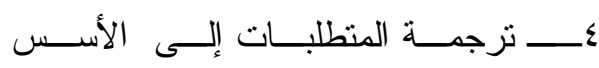

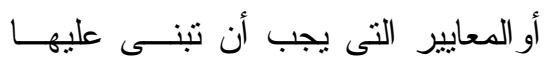

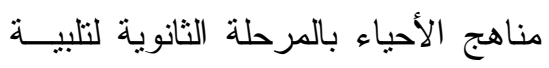

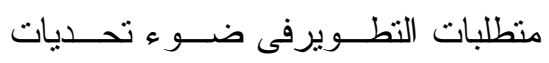
القرن الحادى و العشرين.

○ــ إعداد تصور مقترح لمنــاهج الأحيــاء

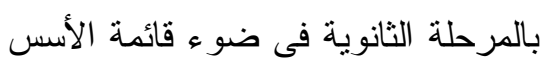
كما يلى : بالم ـ تحديد الأهداف العامة للمناهج المطورة. ـ ـ تحديد الإطار العام لمحتويات المنــاهج

$$
\text { المطورة. }
$$

ـ تحديد طرق التدريس و الأنشطة و المو اد

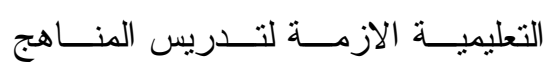

$$
\text { المطورة . }
$$

ـ - تحديد أساليب التقويم للمناهج المطورة. 7- عرض التصور المقتر ح لمناهج الأحياء

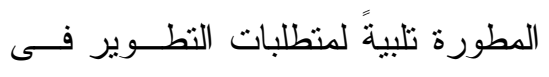
ضوء تحديات القرن الحادى و العـشرين

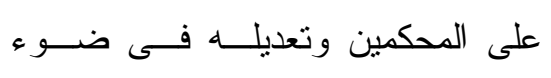

$$
\text { آر ائهم. }
$$

V- إعداد كتاب الطالب المــزود بالأنـشطة للوحدات المطورة بحيث يتم تدريسه فى فصل در اسى كامل بما يتو افق مع تلبية

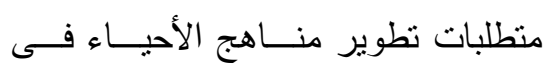

مجردة إلى التفكير الثامل (عفانة ،نــشوان ، مان . (Y) 96 . T . .

تحديات القرن الحادى والعسشرين :

المشكلات التى تواجه العالم خلال هذا القرن

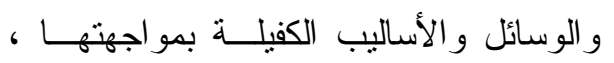
و اقتر اح الحلول الموضوعية لكل مشكلة .

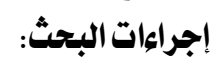

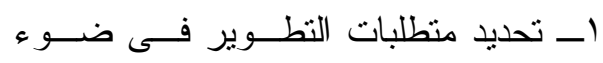
تحديات القرن الحادى و العشرين المراد

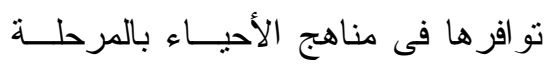
الثانوية وذلك كما يلى ـ الإطلاع علــى الأدبيــات و الدر اســـات

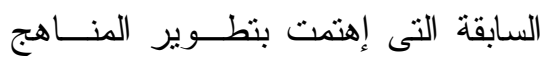

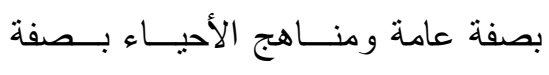
خاصة . r- وضع الصورة الأولية لقائمة منطلبــات

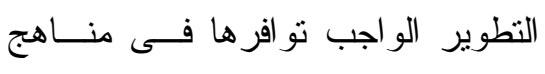

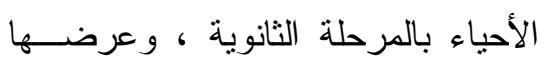

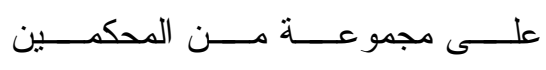
المتخصصين للنأكد من صــدقها ، ثـم فئ

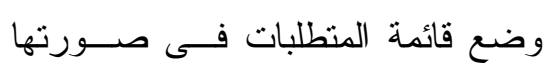
النهائية . وصيع فه rـ تضمين قائمة متطلبات التطوير فى أداة لتحليل مناهج الأحياء بعناصر ها المتمثلة فى (الأهداف ،المحتوى، أنشطة التعلــيم

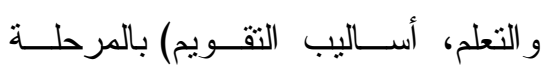


r إ- تحديد العينة الأساســية للبحــث مــن

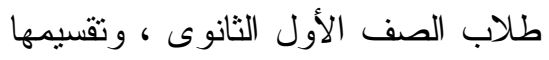
إلى مجمو عتن تجريبية وضابطة .

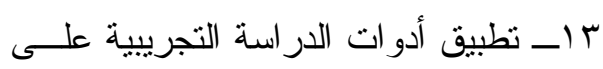
عبنة الدر اسة قبلياً.

ـ إ_ تدريس الوحدتين المحددنين للمجموعة

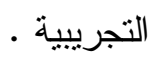

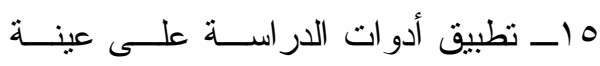
البحث بعدياً. 17 الإحصائية بعدياً.

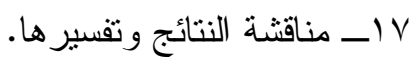
1اــ تقديم التوصيات و المقترحات فى ضو ه ما أسفرت عنه النتائج. نتائج البحث اــ مناهج الأحياء بالمرحلة الثانوية لاتلبى متطلبات القرن الحادى و العشرين . r- يوجد فرق دال إحصائيا عند مسـستوى دله دلاله (0., •) بين متوسطي درجــات

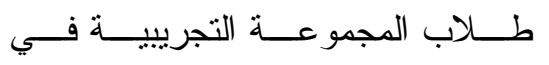
التطبيقين القبلـي و البعــدي لاختبــار التفكير الناقد لصالح النطبيق البعدي". r-ـ يوجد فرق دال إحصائيا عند مسـستوى دل دلاله (0., •) بين منوسطي درجـات

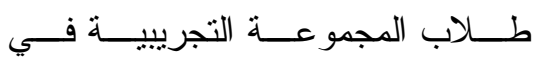
التطبيقين القبالــي و البعـــي لاختبـــار
ضوء تحديات القرن الحادى و العـشرين

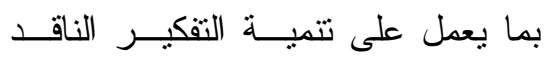
و التفكير المنظومى لدى طلاب المرحلة

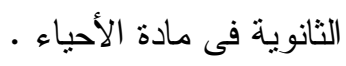
ᄉ - إعداد دليل المعلم للوحـــات المحــددة بحيث يسترشد به المعلــم فــى تتميــة

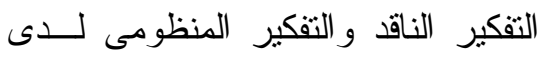
طلاب المرحلة الثانوية فى مادة الأحياء. 9- عرض كتاب الطالب المدعم بالأنشطة ،

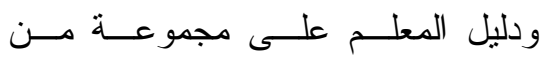
المحكمين المتخصصين فــى المنــاهج

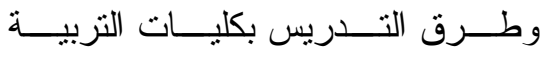

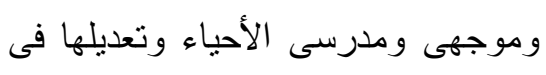

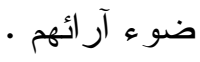

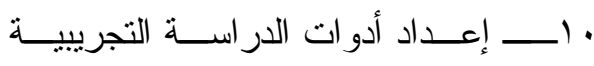

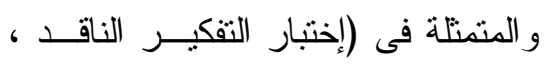
إختبار التفكير المنظومى، مقياس الوعى الونى

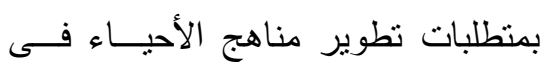
ضوء تحديات القرن الحادى و العشرين. إ- عرض أدوات الدر اسة على مجموعة من المحكمين للتأكد من صدق المحتوى لدو لات و إجر اء التعديلات فى ضو ء آر ائهم ثــم إجر اء التطبيــق الإســنطلاعى لأدوات الدراسة التجريبية على عينة من طلاب الجي

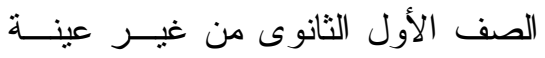

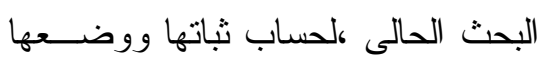
فى صورتها النهائية . 


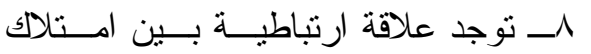

$$
\begin{aligned}
& \text { طلاب الصف الأول الثانوي الدارسـين } \\
& \text { لمنهج الأحياء المطور لتلبية منطلبـات الاول } \\
& \text { التطوير في ضـــوء تحـــديات القــرن } \\
& \text { الحادي و العشرين ومستويات تفكيـــر هم } \\
& \text { الناقد و التقكير المنظومي ولعين ومنئ }
\end{aligned}
$$

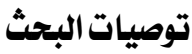

فى ضو و ما أســفرت عنـــه نتــائج البحث ، يوصى الباحث بالآتى :

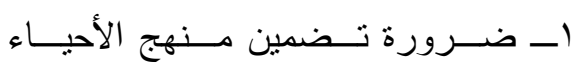
بالمرحلة الثانوية مزيد مــن المفــاهيم

الصحية الوقائية منل أمر اض العصر مزئل

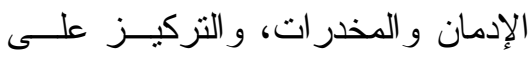
الجانب الوقائى أكثر من كونهــا مــادة ولئ

$$
\text { علمية . }
$$$$
\text { r- ضرورة نشر الوعى الصحى الغــذائى }
$$

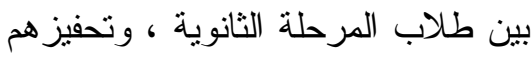$$
\text { على إتباع القو اعد السليمة فى التغذيــة }
$$$$
\text { من خلال المنهج الباع الهواع }
$$$$
\text { r- ضرورة الربط المستمر فـى مسنـهج }
$$

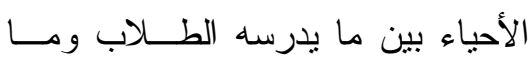

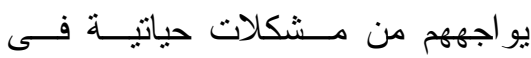

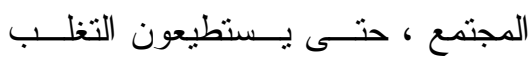

$$
\text { عليها. }
$$

عـــ استخدام التكنولوجيــا المتعـددة فـى

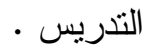

التفكير المنظــــومي لــصالح التطبيــق

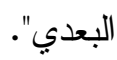

عـ يوجد فرق دال إحصائيا عند مـستوي

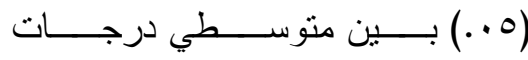

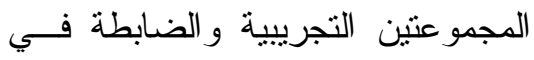

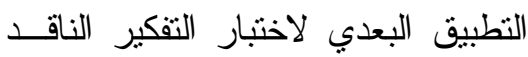
لصالح المجموعة التجريبية". 0ـ "يوجد فرق دال إحصائيا عند مسستوي

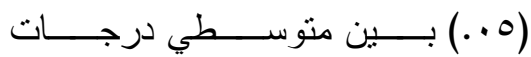
المجموعتين التجريبية و الضابطة فـي ليـي التطبيــق البعــــي لاختبـــار التفكيــر

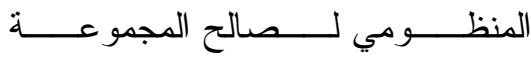

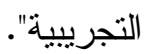
T- "يوجد فرق دال إحصائيا عند مـستوي

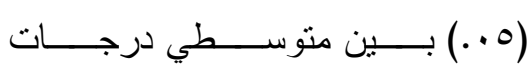
المجموعنين التجريبية و الضابطة فـي لـي دئي

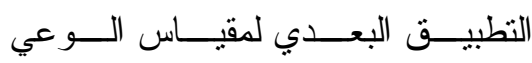
بمنطلبات القرن الحــادي و العـشرين وتطبيقاتها في الحياة و العدـلـل لــصالح طلاب المجموعة التجريبية". У- يوجد فرق دال إحصائيا عند مـسنتوي

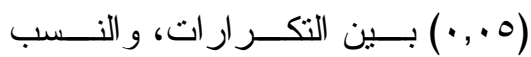

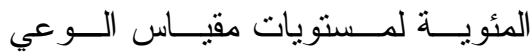
بمنطلبات تطوير منهج الاحياء (منوفر

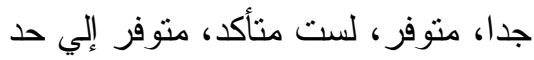

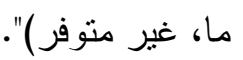


r- تقويم مستويات إمتلاك طلاب المرحلة

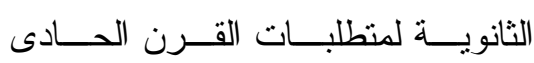

و العشرين ذات الصلة بدر اســة مــنـهج

$$
\text { الأحياء . }
$$

عـــ إعداد منهج الأحياء للمرحلة الثانويـــة

فى ضوء المدخل الإستقصائى متعـدد

$$
\text { · النظم }
$$

○ـ بناء منهج مقترح فى الأحياء مت ضـنـاً

وحدتى السلوك و التطور وتحديد فاعليته

$$
\text { فى تحقيق أهداف تدريس المادة . }
$$

7- تطوير منهج الأحياء بالمرحلة الثانوية

فى ضوء مدخل التحليل الأخلاقى .

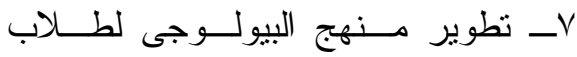

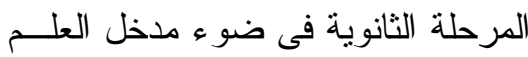

و التكنولوجيا و المجتمع •

^ــ تطوير منهج الأحياء بالمرحلة الثانوية

فى ضوء المدخل البيئى .

9- تقويم منهج الأحياء بالمرحلة الثانويــة

$$
\text { فى ضوء المدخل التكاملى . }
$$

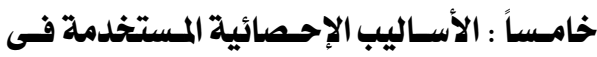

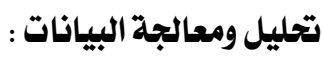

تم إستخدام برنامج الحزم الإحصائية

$$
\text { spss }
$$

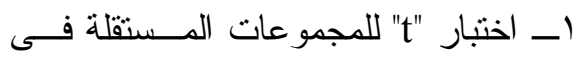

المقارنة بين المجمــوعنين الــضابطة

و التجريبية فى كل من التطبيقين القبلــى و البعدى وذللك فــى (اختبــــار التفكيـــر

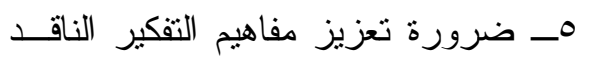

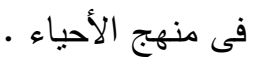

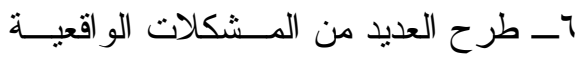

$$
\text { ضمن منهج الأحياء. }
$$

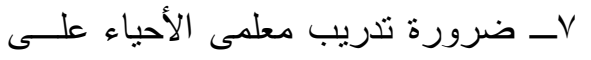

تتمية مهار ات التفكير الناقد حتى يمكنهم

تتميتها لاى الطلاب بالمرحلة الثانوية .

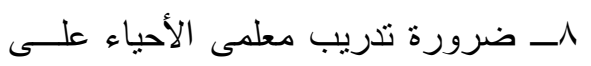

تتمية مهار ات التفكير المنظومى حتهى لـى لاحياء

$$
\text { ويمكنم نقلها إلى الطلاب . }
$$

9ــ تأكيد الصلة بـين الأحيــاء و العلـــوم

$$
\text { الأخرى ناكي }
$$

• إ- التأكيد على الإستقصاء العلمى .

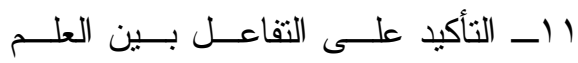

و التكنولوجيا و المجتمع و البيئة عند بناء مناهج الأحياء بالمرحلة الثانوية .

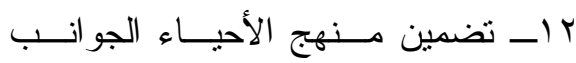

الأخلاقية المرتبطة بمستحدثاتها الحيوية

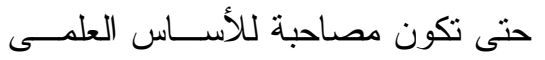

\section{بحوث مقتزحة}

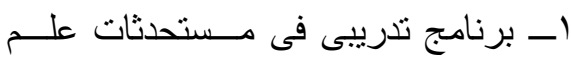

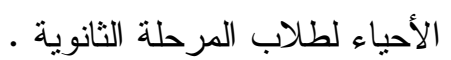

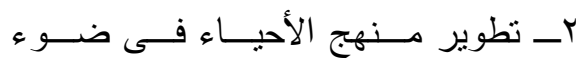

مهار ات التفكير العلمى من خلال بر امج

التقنية الحديثة و الإستر اتيجيات المختلفة. 
(القاهرة مركز معلومات الثرق تيـسير

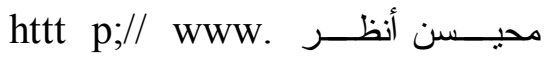

Gov.ps/Arabic/roya/29/pages.h

tml

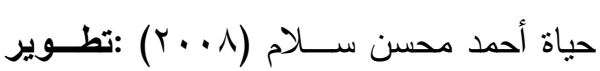

مناهج الغلوم بمرحلة التعليم الأساسى لهن

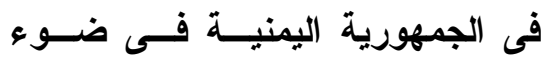

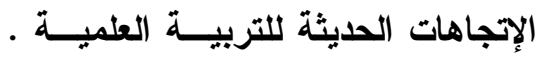

رسالة دكتور اة غير منــشورة ، كليــة

التزبية ، جامعة عين شمس .

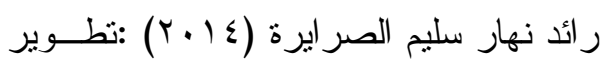

منهج الأحياء فى ضوء مدخل العمليات

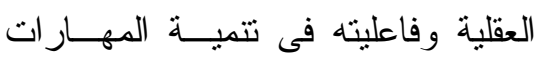

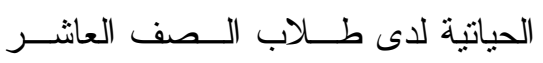

$$
\text { الأساسى بالأردن }
$$

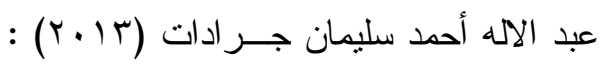
أثز برنامج إثرائى فى مــادى الأحيــاء

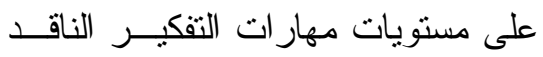
و اكتساب المفاهيم العلمية و الاتجاهــات

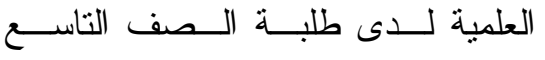

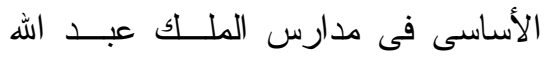

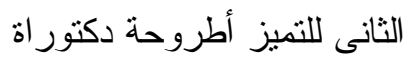

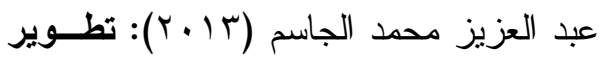

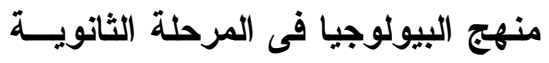

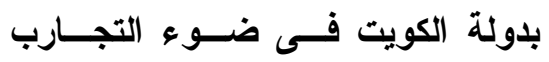

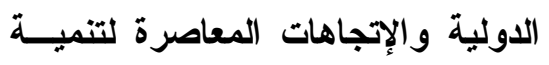
بعض المهارات الحياتية والإتجاه نحو

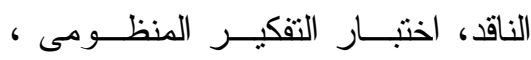
ومقياس الوعى بمنطلبات القرن الحادى

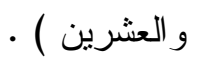

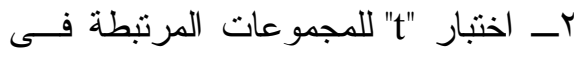

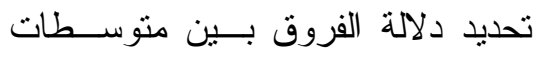

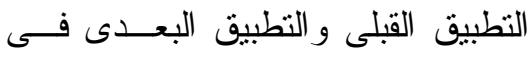

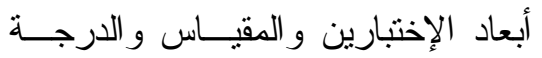
الكلية وذللك للمجموعة التجريبية لتحديد فعالية وحدة التجريب فى نتمية كل من

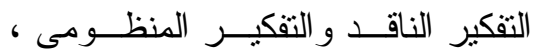
و إمتلاك الطــلاب لمتطلبـــات القــرن

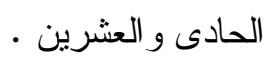
بــ مقياس حجم التأثثر (إيتاً) لبيان حجــ تأثير وحدنى التجريب فى تتمية كل من

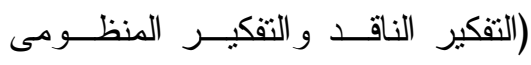
و إمتلالك الطــلاب لمنطلبـــات القــرن

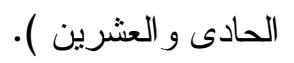

المراجع: - اج

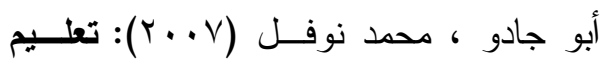
التفكير النظرية والتطبيق، دار المسيرة، عمان.

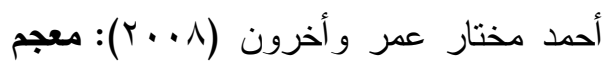

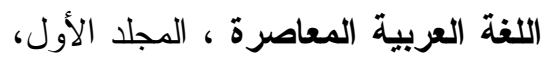

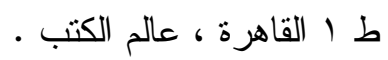
برنامج الأمم المتحدة الإنمائى تقرير التتميــة

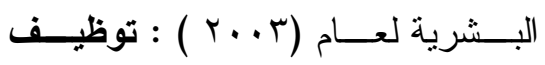
التقنيات الحديثة لخدمة التنمية البشرية 
على المدخل البيئى فى تنمية المفــاهيم البيولوجية والتفكير العلمى والإتجاهات

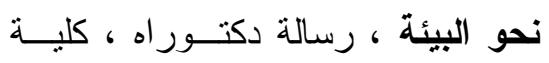

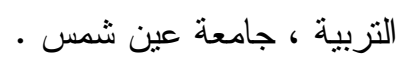

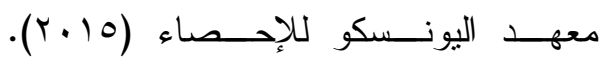
تكنولوجيا المعلومات و الاتصالات فــي لئولي التعليم في خمس دول عربيـــة :تحليـلــل

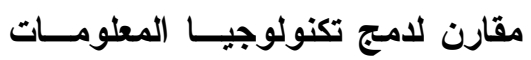
و الاتصالات والجاهزية الإكترونية في لأني المدارس في مــصر والأردن وعمــان وفلسطين وقطر.

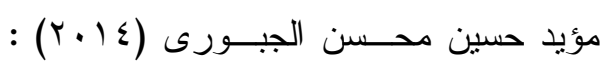
فاعلية برنامج (Risk) فى التحـصيل مئل وتنمية التفكير الناقد فى مادة الأحيـاء ،رسالة ماجستير •

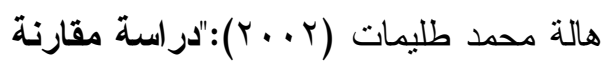
لاى تمكن كلاً من متخرجى كلية التربية

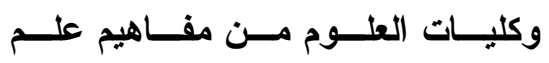

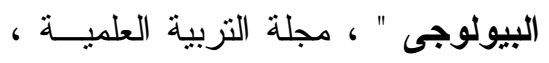

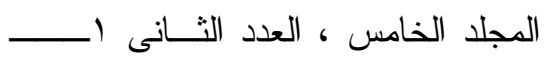
ro

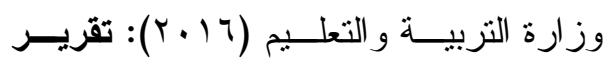
ورشة عمل اللجنة القومية لمراجعـة مناهج العلوم والرياضيات . ماندل

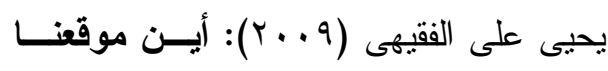
منها؟ برامج ومشاريع إصلاح تعلـيم

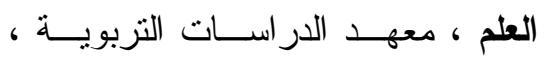

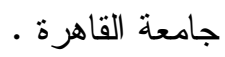

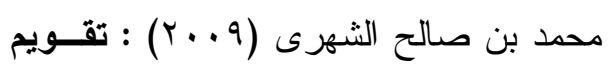
محتوى كتب الأحياء بالمرحلة الثانوية فى ضوء مـستحدثات عـــم الأحيـاء

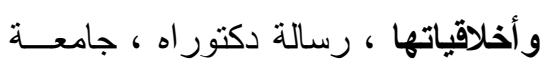

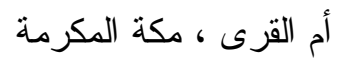

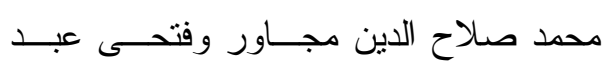

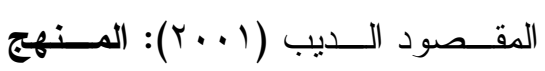

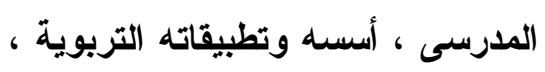
طا، الكويت ، دار القلم.

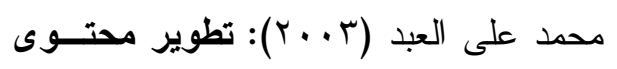

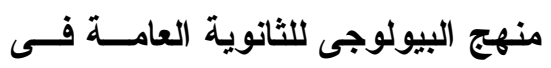

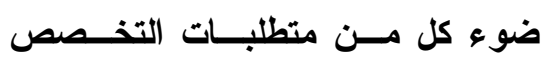

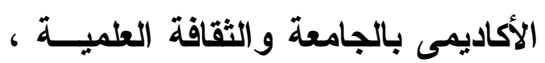
رسالة دكتور اه غير منــشورة ، كليــة التزبية ، جامعة الأسكندرية .

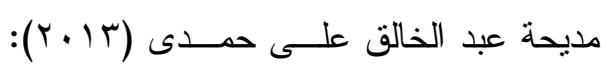

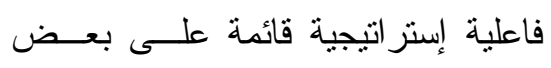
أساليب النعلم النشط في تنمية المفــاهيم

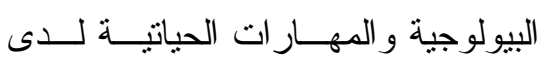
طلاب المرحلة الثانوية ، رسالة دكتور اة

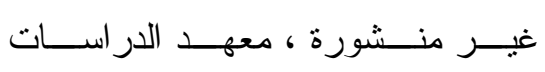
التزبوية، جامعة القاهرة . مرفت رشاد أحمد (10 ب) : فاعلية منهج مقترح للبيولوجى للمرحلة الثانوية قائم 
Biological Sciences Curriculum Study (BSCS)(2004):BSCS Biology :AHuman Approach, BSCS. Colorado Spring, Colorado. Biology Curricula. Colorado Springs. Colorado.

Blank, Rolf K. et. al (2001). New Tools for Analyzing Teaching, Curriculum and Standards in Mathematics \& Science.https://secure.wceruw. org/seconline/Reference/SECn ewToolsreport.pdf

Burrows, A. C., Breiner, J. M., Keiner, J., \& Behm, C. 2014. Biodiesel and Integrated STEM: Vertical Alignment of High School Biology/Biochemistry and Chemistry. Journal of Chemical Education, 91 (9), Sep, 1379-1389.

Bybee, W. Rodger (2010). The Teaching of Science: 21st Century Perspectives, NSTA press.

www.sbcf.fr/.../The_Teaching _ of_Science-Ch_7_march..

Collins, D. et al., (2001): What "Ideas about Science" Should be Corporation, BSCS, Colorado Spring, Colorado Glencoe / Mc Graw- Hill.

Hiong, Lee Chuo and Osman, Kamisah(2013). A Conceptual Framework for the Integration of 21tCentury Skills in BiologyEducation. Research
مارس و . العلوم العالمية ، مجلة المعرفة ، عـدد

Anderson,K.(2012):Science

Education And Test-Based Accountability: Reviewing Their Relationship And Exploring Implications for future policy, Science Education,96 (1) :104-129.

Approach , 9th Edition (BSCS)Green Version Introductory Biology, Kendall/

Assessment \& Teaching of 21

Centuryskills

(2013).

Assessing 21st century skills.atc21s.org/

Association of American college \& universities (2007). College learning for the newcentury.www.aacu.org/lea p/documents/GlobalCentury_fi nal.pdf Biological Literacy, A Guide to Developing secondary and post Secondary

Biological Sciences Curriculum Study (BSCS) (1993): Developing

Biological Sciences Curriculum Study (BSCS) (2001): BSCS Biology:

Biological Sciences Curriculum Study (BSCS)(2002): BSCS Biology: An Ecological

Biological Sciences Curriculum Study (BSCS)(2003): Journal of The National Selection,Fall 2003. 


\section{1st Century: \\ Research,Innovation and \\ Policy \\ www.oecd.org/site/educeri21st /40554299.p}

Schultz, R. H. 2012. AP Biology

Course Syllabus 2012-2013.

Murrieta Mesa High School.

http://mesabiology.wikispaces. com/

Saavedra, R. Anna and Opfer, V. Darleen(2012). Learning 21stCentury Skills Requires, 21stCentury Teaching, Phi DeltaKappan, (94) 2, 813.http://teacherweb.com/PA/T heCampusSchoolofCarlowUni versity/MrsMichellePedto/2 1st-Century-Learning.pdf

Smith,K.(2010):Curriculum: The Case for Basic Sciences In The Undergraduate Curriculum, The Clinical Teacher,7(2):211-214.

Sungur,S ,Tekkaya,C,\& Geban, $\mathrm{O}(2006) \quad$ :Improving achievement through problem based learning, Journal if Biological Education (JBE) ,Vol. (40) ,No.(4) ,pp.155-160.

Felicia WU, and Williams Butz., "the Future of Genetically modification Crops", R\&D Publications, Amazon Com. Dist., US (2004).

Huitt,w.(1998),Critical Thinking ;an overview, educational psychology interactive ,valdostata university.
Journal of Applied Sciences, Engineering and Technology6(16): 2976-2983 Hunt Publishing

Kennedy C.E.,G.J.,"Analysis of Accelerated Exposure Testing of a Thin Glass Matrix" ,in Proceedings of the International Solar Energy Conference, Orlando, American Society of Mechanical Engineers, 6-12 August (2005).

Mijung, K., \& Diong, C. H. (Eds.). 2012. Biology Education for Social and Sustainable Development. Sense Publishers.

National Academy of Science, 2014. Capturing Change in Science, Technology, and Innovation: Improving Indicators to Inform Policy. Washington, DC. USA. National Research Council, 2009. A New Biology For The 21st Century. Washington, DC: The National Academies Press.

National Science Teachers Association. 2013. Next Generation Science Standards. High school Life Science. Achieve, Inc.

OECD (2005). 21st Century LearningResearch, Innovation and Policy.

OECD/CERI International Conference"Learning in the 
The University of Arizona (2004): Biotech Project, Mobile Veronica Garcia, Lournal of Cleaner Production. Vol.39,Elsevier publishing, Amsterdam, the Netherlands,(2012).

Veronica Garcia, Lournal of Cleaner Production. Vol.39,Elsevier publishing, Amsterdam, the Netherlands,(2012).

Yalcin , B.M.,Karahan , T.F.,ICaradenizi,D., \& Salin,E. M.,(2006).Shortterm Effects of problem -based Learning Curriculum on Student Self directed Skills Development Coart Med Journal., No.(47) ,pp.491-498.
The Partnership for 21st Century Skill(2006a), Framework for 21 st

CenturyLearning.http://www.p 21.org/overview/skillsframewo rk

The Partnership for 21st Century Skill(2006b). Results that matter:21st century skills and high school reform. http://www.21stcenturyskills.or g/documents/RTM2006.pdf

The Partnership for 21st Century Skill, Designed in cooperation with The National Science Teachers Association (2009). 21Century SkillsMap.http://www.p21.org/ storage/documents/21stcskills map_science.pdf 